LOCAL VERSUS AGGREGATE

LENDING CHANNELS:

THE EEFECTS OF SECURITIZATION ON CORPORATE CREDIT SUPPLY

Gabriel Jimenez. Atif Mian.

Jose - uirs Peydro and Jesus Sauma.

Documentos de Trabajo

N. 1124

banco gespaña

Eurosistema

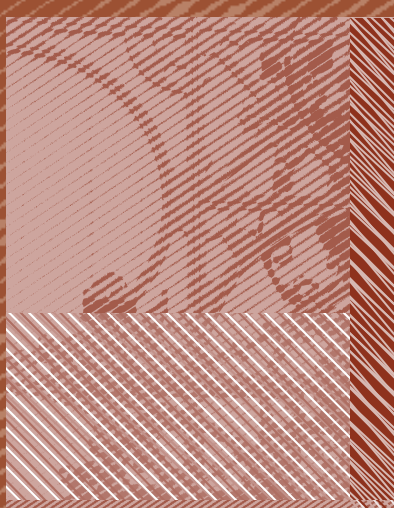


LOCAL VERSUS AGGREGATE LENDING CHANNELS:

THE EFFECTS OF SECURITIZATION ON CORPORATE CREDIT SUPPLY 


\title{
LOCAL VERSUS AGGREGATE LENDING CHANNELS: \\ THE EFFECTS OF SECURITIZATION ON CORPORATE \\ CREDIT SUPPLY ${ }^{(*)}$
}

\author{
Gabriel Jiménez
}

BANCO DE ESPAÑA

\author{
Atif Mian \\ UNIVERSITY OF CALIFORNIA BERKELEY \\ José-Luis Peydró \\ ECB AND UPF AND BARCELONA GSE \\ Jesús Saurina \\ BANCO DE ESPAÑA
}

(*) The results or views expressed in this study are those of the authors and do not necessarily reflect those of the Banco de España, European Central Bank or the Eurosystem. Corresponding authors: atif@haas.berkeley.edu and jose.peydro@gmail.com. We thank Michael Weber for excellent research assistance and Asim Khwaja and Amir Sufi for extremely helpful comments and discussion. We would also like to thank seminar participants at the University of Chicago Booth School of Business, European Central Bank, MIT, Universitat Pompeu Fabra, New York Federal Reserve, University of Michigan (Ross), Notre Dam, and University of California Berkeley and also Joshua Angrist, Xavier Freixas and Jaume Ventura for helpful comments. Financial support from the Coleman Fung Risk Management Research Center at University of California Berkeley is gratefully acknowledged. 
The Working Paper Series seeks to disseminate original research in economics and finance. All papers have been anonymously refereed. By publishing these papers, the Banco de España aims to contribute to economic analysis and, in particular, to knowledge of the Spanish economy and its international environment.

The opinions and analyses in the Working Paper Series are the responsibility of the authors and, therefore, do not necessarily coincide with those of the Banco de España or the Eurosystem.

The Banco de España disseminates its main reports and most of its publications via the INTERNET at the following website: http://www.bde.es.

Reproduction for educational and non-commercial purposes is permitted provided that the source is acknowledged.

() BANCO DE ESPAÑA, Madrid, 2011

ISSN: 0213-2710 (print)

ISSN: 1579-8666 (on line)

Depósito legal: M. 39738-2011

Unidad de Publicaciones, Banco de España 


\section{Abstract}

While banks may change their credit supply due to bank balance-sheet shocks (the local lending channel), firms can react by adjusting their sources of financing in equilibrium (the aggregate lending channel). We provide a methodology to identify the aggregate (firm-level) effects of the lending channel and estimate the impact of banks' ability to securitize realestate assets on credit supply for non real-estate firms in Spain over 2000-2010. We show that firm-level equilibrium dynamics nullify the strong local (bank-level) lending channel of securitization on credit quantity for firms with multiple banking relationships. Credit terms however become softer, but there are no real effects. Securitization implies a credit expansion on the extensive margin towards first-time bank clients, which are more likely to default. Finally, the 2008 securitization collapse reverses the local lending channel.

Keywords: Bank lending channel, credit supply, credit demand, macroprudential, real economy effects of finance, securitization.

JEL classification: G21, G28, G01, G30, E44, E50. 


\section{Resumen}

Mientras que los bancos pueden cambiar su oferta de crédito tras sufrir shocks que afectan a sus balances (el canal local del préstamo), las empresas pueden reaccionar ajustando sus fuentes de financiación en equilibrio (el canal agregado del préstamo). En este papel proporcionamos una metodología para identificar los efectos agregados (a nivel de empresa) del canal del préstamo y estimamos el impacto que la habilidad de los bancos para titulizar activos inmobiliarios tienen sobre la oferta de crédito para las empresas no financieras en España en el periodo 2000-2010. Mostramos que las dinámicas del equilibrio a nivel de empresa-banco anulan el fuerte canal del préstamo observado a nivel local (nivel de banco) de la titulización sobre la cantidad de crédito para las empresas con múltiples relaciones bancarias. Sin embargo, las condiciones de los préstamos se suavizan aunque no existen efectos reales. La titulización implica una expansión de crédito en el margen extensivo hacia clientes nuevos, que son más propensos al impago. Finalmente, el colapso de la titulización en 2008 invierte el canal local del préstamo.

Palabras claves: Canal del préstamo de los bancos, oferta de crédito, demanda de crédito, macroprudencial, efectos económicos reales de las finanzas, titulización.

Códigos JEL: G21, G28, G01, G30, E44, E50. 


\section{Introduction}

The banking sector often takes center stage in economic controversies. Banks are accused of excessive credit creation and asset bubbles on the upside, and of being too stingy with credit on the downside, with important consequences for financial stability and economic activity. The primary suspect in such scenarios is the credit supply channel, i.e. credit growth (or lack thereof) dictated by frictions in the credit supply process rather than economic fundamentals. Securitization has been over the last decade a crucial financial instrument and, by affecting bank capital and liquidity, may have strongly influenced credit supply (Shin, 2009). ${ }^{1}$

While shocks to balance sheets of banks may have real effects via credit supply (Bernanke 1983; Holmstrom and Tirole 1997; Diamond and Rajan 2006; Allen and Gale 2007; Kiyotaki and Gertler, 2010; Adrian and Shin, 2010; Shleifer and Vishny, 2010; Stein 1997 and 2011), how do we know that observed fluctuations in credit are driven by supply shifts, and not by demand fundamentals? Most calls for policy makers to "lean against the wind" in the midst of a credit boom, or to subsidize banks in a credit crunch as in the recent crisis with trillions of euros, are based on the premise that the primary failure lies on the supply side.

Furthermore, it is increasingly recognized that credit supply side failures at the bank level (the "local" lending channel effect) only reflect partial equilibrium outcomes. The general equilibrium effects could be very different and require a "macroprudential approach" (Trichet 2009; Hanson, Kashyap and Stein, 2010). For example, a reduction in credit supply due to an adverse balance sheet shock to some banks may not have any negative real effect if affected firms can go elsewhere to compensate for the loss in credit. We refer to the latter response as the "aggregate" lending channel effect. Indeed proponents of non-interventionist central banking, such as Mulligan (2008), argue that such general equilibrium effects are strong enough to let credit markets heal on their own. Unnecessary interventions, they argue, create more mischief by punctuating the virtuous cycle of creative destruction.

\footnotetext{
${ }^{1}$ Bank capital and liquidity influence the severity of frictions stemming from moral hazard, adverse selection and coordination problems in banks (see e.g. Diamond and Rajan, 2000; Morrison and White, 2005; Goldstein and Pauzner, 2005). Therefore, securitization of real estate assets - by affecting bank balancesheet strength (capital and liquidity) - makes credit supply endogenous to securitization, even for the loans to the non-real estate sector (see e.g. Shin, 2009).
} 
This paper formalizes a methodology that estimates the supply side effects of aggregate (and local) bank lending channels and applies our methodology to estimate the aggregate and local effects of securitization on the supply of credit.

First, our approach separates the impact of supply from demand of credit while taking into account firm-level equilibrium adjustments. It builds upon earlier work by Khwaja and Mian 2008 (KM henceforth). KM estimate the (local) supply-induced credit channel effect at the loan-level by using firm fixed effects that absorb credit demand shocks (fundamentals) experienced by a firm. To analyze the (aggregate) firm-level credit supply implications, we extend this technique by estimating the otherwise unobservable covariance between bankspecific credit supply shocks and firm-specific credit demand shocks. We then use this covariance term to construct an unbiased estimate of the aggregate impact of the bank lending channel that explicitly takes into account firm-level equilibrium adjustments.

Second, we identify the effects of banks' ability to securitize real-estate assets on credit supply for non real-estate firms. Using the exhaustive credit from Spain over 2000Q1-2009Q4, we investigate the possible lending channel consequences of securitization for credit volume, terms and defaults and also for firm real effects. The rapid expansion in global market for securitized products enabled Spanish banks - especially those with large real estate assets to potentially access wholesale financing by securitizing their real estate assets. ${ }^{2}$

Using ex-ante variation in real estate holdings to proxy for the capacity of banks to securitize assets during the securitization boom, we test whether securitization of real estate assets expanded credit supply and encouraged riskier lending in the non-real estate sectors of the economy. ${ }^{3}$ We utilize a comprehensive loan level data set for this purpose from the credit register of the Bank of Spain. The data include loan level information for all bank loans granted at quarterly frequency from 1999Q4 to 2009Q4 in Spain, a bank dominated financial system. This information is then merged with balance sheet information for the borrower (firms) and the lender (banks).

\footnotetext{
${ }^{2}$ We use the term "securitization" to include both covered bonds and asset-backed securities.

${ }^{3}$ Shin (2009) presents a possible mechansim through which securitization might impact credit supply for all type of loans. More generally, securitization by affectting the ability to access future liquidity (against illiquid assets) it can affect current bank credit supply for all type of loans (see e.g. Diamond and Rajan, 2006; Allen and Gale, 2007).
} 
We show that securitization is indeed higher for banks with more real estate assets before the boom, and that these banks have stronger ex-post credit growth for non-real-estate firms. We use firm fixed-effects to absorb firm fundamentals (credit demand shocks) at borrowerlevel and show that the securitization-induced credit growth is primarily driven by changes in the banks' credit supply. Thus improved access to wholesale financing allows banks to increase credit supply. The effect is also economically large: one standard deviation increase in ex-ante exposure to real estate more than doubles the growth in credit supply to non-realestate firms between 2004 and 2007.

Despite a large local lending channel effect at the bank-firm level, the net impact of securitization at the firm level - the aggregate lending channel - is significantly lower due to "crowding out" of credit at the firm level. Crowding out may occur for several reasons: First, some firms may not be credit constrained and, hence, may not want to increase their net borrowing. If a bank offers to increase its credit supply for such a firm, the firm is likely to demand better terms and likely to cut back its borrowing from other banks. Second, even for firms that are credit-constrained, banks may not be willing to go beyond the firms' total debt capacity. ${ }^{4}$ A unique advantage of our methodology is that we can incorporate such crowding out effects and still isolate credit supply from demand.

We find strong support for the crowding out hypothesis. For the set of firms with multiple borrowing banking relationships at the time of securitization boom, the aggregate lending channel effect is close to zero despite a large local lending channel effect for these firms! ${ }^{5}$ Crowding out thus dramatically reduces the net impact of securitization-induced credit supply on the quantity of credit.

There is, however, a significant impact on the price of credit in the aggregate lending channel. We show that firms with unused lines of credit start to disproportionately fa-

\footnotetext{
${ }^{4}$ Due to agency problems (e.g., Stiglitz and Weiss (1981), Holmstrom and Tirole (1997)), a lower cost of debt (from credit supply shocks) may not translate into higher aggregate firm-level credit volume. For example, total borrowing capacity of firms may be fixed in the short run if they need to have scarce collateral or equity to credibly commit to banks against future misbehavior. In such a scenario, greater willingness by some banks to lend is likely to lead to a shift in borrowing towards banks that want to expand credit rather than an aggregate (firm-level) increase in lending.

${ }^{5}$ As we explain in detail later, these results are based on firms with multiple banking relationships at the start of securitzation boom in 2004 (so that we can use firm fixed effects to control for firm fundamentals in loan-level regressions). Such firms represent almost 80 percent of overall bank credit in Spain.
} 
vor banks with greater access to securitization, suggesting improved credit terms through a revealed preference argument. Consistent with this interpretation, we also find that securitization leads to a reduction in the rate of collateralization and a lengthening of loan maturity. All these results suggest that securitization leads to softer lending terms for borrowers.

Despite the zero aggregate impact of securitization-induced credit supply channel on the quantity of credit, there could be some positive real effects through the effect on credit terms. However, we find no evidence of any impact on real firm outcomes, including firm sales, employment, and default rate.

The results above are based on firms that already have borrowing relationships at the time of securitization boom. When we look at the effect of securitization on the extensive margin of lending to new clients, we find a large effect on credit quantity. Growth in credit to new clients between 2004 and 2007 is much stronger for banks with greater exposure to securitization. A one standard deviation increase in ex-ante exposure to real estate assets generates credit to new clients that is equivalent to 10.7 percent of bank assets. Moreover, new credit granted is riskier for banks with higher ex-ante real estate assets, as it is about a third more likely to default.

All in all, securitization leads to softer credit terms for firms with established access to credit but has no impact on their total borrowing or real outcomes. However, it does have a large effect on credit extension to new clients that turn out to be significantly more risky. The expansion in credit adds fragility to the financial system as new loans are significantly more likely to default during the downturn. ${ }^{6}$

Finally, we analyze whether the 2008 collapse in the securitization market implies a credit crunch. There is a sharp reversal in the local lending channel as banks with higher ex-ante exposure to real estate significantly cut back their credit supply. However, the aggregate impact is more modest as firms are partially able to adjust their borrowing from other (less affected) banks.

\footnotetext{
${ }^{6}$ These results are consistent with Shin (2009), as his model suggests that securitization - by increasing credit supply to marginal, new borrowers - increases credit risk, and hence can be detrimental for financial stability (see also Dell'Ariccia and Marquez (2006) and Broecker (1990) for theories in which higher loan defaults stem from banks' lending to new borrowers in expansions). Results are also consistent with models in which higher bank liquidity implies more risk-taking in bank lending due to banks' moral hazard (see e.g. Allen and Gale, 2007; Diamond and Rajan, 2001).
} 
Our paper contributes to the literature on bank transmission mechanism in several ways. ${ }^{7}$

First, we are the first to formally incorporate the equilibrium feedback effects from borrowers when estimating the bank transmission channel (while still isolating credit supply from firm fundamentals). ${ }^{8}$ As theory shows, the bank lending channel is important only if there are real economy or financial stability implications. Therefore, it is crucial to identify the aggregate (firm-level) effects of the banking lending (supply) channel. The results of some of the previous studies that estimate the transmission channel at the bank level - such as Kashyap and Stein (2000) - may be incomplete without incorporating firm level equilibrium responses. Indeed, our own analysis of Spanish banks reveals that while the bank transmission mechanism is strong, its aggregate (net) impact is reduced due to the firm level crowding out effect for large segments of the economy.

Second, the role of financial innovation in precipitating credit booms and subsequent financial crises through the financial intermediary system is emphasized by numerous economic historians (e.g. White (1996), Calorimis (2008), Bordo (2009) and Kindleberger (1978)). Most recently, Kohn (2009) notes "the tendency for financial crises to be preceded by bubbles spurred by financial liberalization or innovations". Our paper provides the first formal evidence on the extent to which financial innovation - in the form of securitization - induces banks to extend more credit supply and at riskier terms.

Third, there is an emerging literature on the effects of securitization on lending. Securitization is associated with lax lending and excessive credit creation in mortgage markets during the 2000's (Keys et al (2010) and Mian and Sufi (2009)). Loutskina and Strahan (2009) show that securitizability of a mortgage loan helps disconnect the dependence of loan origination on bank financials. As Shin (2009) among others show, securitization may affect

\footnotetext{
${ }^{7}$ A partial list on the empirical side includes Bernanke (1983), Kashyap and Stein (2000), Peek and Rosengren (2000), Ashcraft (2005), Paravisini (2008), Maddaloni and Peydró (2011), Iyer and Peydró (2011), Jiménez, Ongena, Saurina and Peydró (forthcoming).

${ }^{8}$ Peek and Rosengren (2000) identify real effects and Paravisini (2008) identifies total borrower debt by exploiting credit supply shocks that are independent of economic fundamentals. However, given that the majority of interesting shocks to banks (e.g. crises, runs, monetary policy, capital) are not independent of economic fundamentals, a key contribution of our paper is to incorporate a general methodology to identify the aggregate lending (supply) channel (controlling for observed and unobserved firm fundamentals).
} 
the general supply of credit, thus we contribute to this literature by analyzing the effects of securitization on bank lending standards and credit risk for non real-estate business loans. ${ }^{9}$

Fourth, there is also an emerging literature linking credit supply to capital structure. Faulkender and Petersen (2006) find that firms with a credit rating have higher leverage than those without. Leary (2009) exploits shocks to the US banking system in the 1960s and finds changes in firm capital structure. Rice and Strahan (2010), using the Survey of Small Business Finance, find that changes in banking competition do not affect credit volume but price (Petersen and Rajan (1994) also analyze the SSBF). We contribute to this literature by proposing a way to control for both observed and unobserved firm fundamentals (demand) in order to identify the aggregate firm level impact of credit supply.

Fifth, our proposed methodology uses loan-level credit register data that are increasingly available in many countries around the world. ${ }^{10}$ Our tool is thus practical to implement and should help policy makers gain a better understanding of the overall strength of the credit supply channel in the economy. This is even more important nowadays given the new macroprudential supervision powers for the Fed and the ECB and given also the new bank capital and liquidity regulation (Basel III). Moreover, as observers such as Mulligan (2008) have emphasized, incorporating the borrowing equilibrium effects - that we formalize - is critical for proper evaluation of central bank interventions.

Finally, there is some related work on the Spanish banking system using data similar to ours. Jiménez et al. (forthcoming and 2011) evaluate the credit channel of monetary policy. They find a significant effect of monetary policy on credit supply and risk taking. Our paper differs in its focus on securitization, as well as in introducing a new methodology that incorporates equilibrium crowding out effects. We also provide evidence on real outcomes that earlier studies did not have access to.

The rest of the paper is organized as follows. Section 2 provides the theoretical foundation for our empirical methodology. Section 3 describes the data and institutional details. Sections 4, 5 and 6 present empirical results and section 7 concludes.

\footnotetext{
${ }^{9}$ Our paper is also related to Shivdasani and Wang (2011). They find that the leveraged buyout boom of 2004-2007 was fueled by growth in collaterialized debt obligations (and other forms of securitization).

${ }^{10}$ There are at least 129 countries with either public or private credit registers (Djankov, McLiesh and Shleifer, 2007).
} 


\section{Methodology}

\subsection{Basic Model}

We outline our basic methodology for estimating the net impact of credit supply channel effect. Consider an economy with banks and firms indexed by $i$ and $j$ respectively. Firm $j$ borrows from $n_{j}$ banks at time $t$ and assume (without loss of generality) that it borrows the same amount from each of the $n_{j}$ banks.

The economy experiences two shocks at $t$ : a firm-specific credit demand shock $\eta_{j}$ and a bank-specific credit supply shock $\delta_{i} \cdot \eta_{j}$ reflects changes in the firm's fundamentals as for example productivity or customer demand shocks, which are largely unobserved. $\delta_{i}$ reflects changes in the bank's funding situation, such as a run on short term liabilities (a negative shock) or new opportunities to access wholesale financing (a positive shock). In this paper, $\delta_{i}$ is access to securitization that we proxy with the initial exposure to real estate assets of bank $i$.

Let $y_{i j}$ denote the log change in credit from bank $i$ to firm $j$. Then the basic credit channel equation in the face of credit supply and demand shocks can be written as:

$$
y_{i j}=\alpha+\beta * \delta_{i}+\eta_{j}+\varepsilon_{i j}
$$

Equation (1) assumes that the change in bank credit from bank $i$ to firm $j$ is determined by an economy wide secular trend $\alpha$, credit supply and credit demand shocks, and an idiosyncratic shock $\varepsilon_{i j}$. While equation (1) is reduced form in nature, it can be derived as an equilibrium condition by explicitly modeling credit supply and demand schedules (see KM). We keep the analysis deliberately simple here to focus on the core estimation problem.

In a frictionless world (as in the Modigliani-Miller theorem), bank lending is independent of credit supply conditions and only depends on "fundamental" credit demand factors. Financial intermediaries in such scenarios have no impact on the economy and, hence, there is no bank transmission channel, i.e. $\beta=0$ in equation (1). The presence of financing frictions, however, may force banks to pass on their credit supply shocks $\delta_{i}$ to borrowing firms, making $\beta>0$. 
$\beta$ if often referred to as the "bank lending channel", and we refer to it as the local lending channel in this paper. It can be estimated from (1) using OLS, giving us $\widehat{\beta}_{O L S}=\beta+\frac{\operatorname{Cov}\left(\delta_{i}, \eta_{j}\right)}{\operatorname{Var}\left(\delta_{i}\right)}$. The expression implies that as long as credit supply and demand shocks are significantly correlated, $\widehat{\beta}_{O L S}$ in (1) would be a biased estimate of the true $\beta$. For example, if banks receiving a positive liquidity shock are more likely to lend to firms that simultaneously receive a positive credit demand boost, then $\beta$ would be biased upwards. ${ }^{11} \mathrm{KM}$ resolve this issue by focusing on firms with $n_{j} \geq 2$, and absorbing out $\eta_{j}$ through firm fixed-effects. The estimated coefficient $\widehat{\beta}_{F E}$ then provides an unbiased estimate of $\beta$.

However, $\widehat{\beta}_{F E}$ does not give us a complete picture of the net effect of bank lending channel on the economy. In particular, individual firms affected by the local lending channel due to a positive $\beta$ in equation (1) may seek alternative sources of bank financing to compensate for any loss of credit. Alternatively, if firms benefit from greater provision of credit via a positive credit supply shock to an individual bank, their borrowing from elsewhere may be cut either voluntarily or due to a crowding-out effect. Thus, in order to gain a complete picture of the credit channel effect, one must compute its consequences at the aggregate firm level. We can do so by estimating the firm version of (1):

$$
\bar{y}_{j}=\bar{\alpha}+\bar{\beta} * \bar{\delta}_{j}+\eta_{j}+\bar{\varepsilon}_{j}
$$

$\bar{y}_{j}$ denotes the log change in credit for firm $j$ across all banks. ${ }^{12}$ It is not a simple average of $y_{i j}$ from (1) since a firm can start borrowing from new banks as well (potentially a key margin for firms' adjustment of credit supply shocks). $\bar{\delta}_{j}$ denote the average initial exposure to real estate assets of banks lending to firm $j$ at time $t$, i.e. $\bar{\delta}_{j}=\sum_{i \in N_{j}} \frac{\delta_{i}}{n_{j}}$, where $N_{j}$ represents the set of banks lending to firm $j$ at time $t . \bar{\varepsilon}_{j}$ is an idiosyncratic error term. The same credit demand shock $\eta_{j}$ appears in both equations (1) and (2) under the assumption that the shock on firm fundamentals equally affects a firm's borrowing from all banks.

The aggregate impact of credit supply channel is captured by the coefficient $\bar{\beta}$, which we

\footnotetext{
${ }^{11}$ For example, Caballero, Hoshi and Kashyap (2008) find that banks closer to the minimum capital requirements lend more to low net worth (zombie) firms. In this case, $\delta_{i}$ and $\eta_{j}$ would be correlated.

${ }^{12}$ Depending on data availability, it could include non-bank sources of credit as well.
} 
refer to as the aggregate lending channel. If there is no adjustment at firm-level in the face of bank-specific credit channel shocks, then $\bar{\beta}=\beta$. However if there is some adjustment at firm-level, for example a crowding-out effect, then $\bar{\beta}$ should be less (in absolute value) than $\beta$.

How does one estimate $\bar{\beta}$ ? An OLS estimate of $(2)$ yields $\widehat{\bar{\beta}}_{O L S}=\bar{\beta}+\frac{\operatorname{Cov}\left(\delta_{i}, \eta_{j}\right)}{\operatorname{Var}\left(\bar{\delta}_{j}\right)} \cdot{ }^{13}$ While the variance of $\bar{\delta}_{j}$ can be estimated in data, the covariance term between credit demand and credit supply shocks is unobservable to the econometrician. However, a unique advantage of the preceding fixed-effects estimator at loan level is that it allows us to back-out the covariance term. Since $\widehat{\beta}_{F E}$ is an unbiased estimate of $\beta$, we can write $\operatorname{Cov}\left(\delta_{i}, \eta_{j}\right)=\left(\widehat{\beta}_{O L S}-\widehat{\beta}_{F E}\right) *$ $\operatorname{Var}\left(\delta_{i}\right)$, where variance of bank credit supply shocks $\delta_{i}$ can be estimated directly from data. Thus the aggregate lending channel effect, $\bar{\beta}$, can be estimated as:

$$
\widehat{\bar{\beta}}=\widehat{\bar{\beta}}_{O L S}-\left(\widehat{\beta}_{O L S}-\widehat{\beta}_{F E}\right) * \frac{\operatorname{Var}\left(\delta_{i}\right)}{\operatorname{Var}\left(\bar{\delta}_{j}\right)}
$$

The second term on the right hand side of (3) is the adjustment term that corrects for any bias in the OLS estimate of (2). The adjustment term corrects for the otherwise unobserved covariance between credit supply and demand shocks. The extra variance term in the denominator corrects for the fact that the variance of bank shocks averaged at the firm level may be different from the variance of bank shocks overall.

Equation (3) summarizes our methodology for estimating the net impact of bank credit supply channel. It is simple and practical to implement as loan level credit register data are now available in most countries of the world. The procedure can be summarized as follows. For any given bank shock $\delta_{i}$ that is suspected of generating a transmission channel, run OLS and FE versions of (1) to estimate $\widehat{\beta}_{O L S}$ and $\widehat{\beta}_{F E}$ respectively. Then estimate firm level equation (2) using OLS to generate $\widehat{\bar{\beta}}_{O L S}$. Finally plug these three coefficients in (3) to estimate the unbiased impact of credit supply channel at the firm level.

\footnotetext{
${ }^{13}$ This follows from $\operatorname{Cov}\left(\bar{\delta}_{j}, \eta_{j}\right)=\operatorname{Cov}\left(\sum_{i \in N_{j}} \frac{\delta_{i}}{n_{j}}, \eta_{j}\right)=\operatorname{Cov}\left(\delta_{i}, \eta_{j}\right)$.
} 


\subsection{Calibration and Robustness}

Our model uses simplifying assumptions to keep the analysis tractable. Real world data may not satisfy some of these assumptions. How robust is our core result, i.e. equation (3), to such perturbations? Since close-form solutions are not possible with more generic assumptions, we present numerical solutions to our model under alternative scenarios.

Table I summarizes the results of our simulation exercise. Panel A takes our baseline scenario, i.e. the model presented above, and calibrates it using different assumptions on two key parameters of interest: the (unobservable) correlation between credit demand and credit supply shocks $(\rho)$, and the extent of firm-level adjustment to bank transmission shocks $(\Lambda)$. $\Lambda=100 \%$ implies there is full adjustment at the firm-level making $\bar{\beta}=0$. The calibration exercise assumes that true $\beta=0.5$ and shocks are normally distributed with mean zero and variance equal to 1.0. ${ }^{14}$ The results show that while OLS estimates $\widehat{\bar{\beta}}_{O L S}$ and $\widehat{\beta}_{O L S}$ can be significantly biased with high absolute levels of $\rho$, our fixed-effects and bias-correction procedure in (3) successfully backs out the true coefficients of interest. In a way, Panel A also serves as a "numerical proof" of our baseline methodology.

The baseline analysis assumes that banks continue to lend to firms after realization of shocks. This may not happen in practice. Some loans may be dropped for idiosyncratic reasons and others due to either credit supply or credit demand shocks. Our OLS and FE regressions from the preceding section ignores such dropped loans. Does ignoring dropped loans change the results in Panel A? We test this by simulating dropped loans and then running our estimation procedure on surviving loans. In particular, add a first-stage before our estimation procedure that drops some loans from our sample depending on the loans' credit demand shock, the credit supply shock, and an idiosyncratic factor. The probability of a loan getting dropped is modelled as a probit, with weights on various factors chosen to match what we find in data. ${ }^{15}$ We then rerun our estimation procedure on the remaining sample. The results in Panel B show that our estimate of betas remains valid even when conditioning on loans that do not get dropped. ${ }^{16}$

\footnotetext{
${ }^{14}$ The variance roughly reflects the variance of firm-level credit changes from 2004Q4 to 2007Q4.

${ }^{15}$ We set these parameters such that the coefficient on supply shock is -0.25 (as we will see in column (7) of table 5). The coefficient on demand shock is also assigned the same magnitude. Finally, the level effect is chosen such that about a third of total loans are dropped, as in our Spanish data.

${ }^{16}$ Our model also assumes that each firm borrows the same amount initially from its set of lenders. We also tested for robustness of our results to this assumption by similating borrowing across banks by a firm that matches our data. Our methodology continues to perform very well with these changes.
} 


\section{Data and Institutional Background}

\subsection{Data}

Our data come from loan level credit register of the central bank of Spain (Banco de España), which is also the banking supervisor in Spain. It covers all loans to all non-financial firms. For computational purposes, we restrict to loans with an average borrowing of at least $€ 60,000$. We further restrict the data to non-real-estate loans in order to avoid the concern that our results may be spuriously driven by the boom in real estate sector during our sample period.

The data come at quarterly frequency and cover the period from the fourth quarter of 1999 to the fourth quarter of 2009. The 10 year coverage has the advantage of covering the full lending cycle in Spain. There are 487,090 firms borrowing from any of a possible of 215 banks during this time period. In order to avoid data management issues due to large size, we randomly sample $10 \%$ of the firms based on the random, penultimate digit of the firm fiscal identity number. Once a firm is selected we keep all of its loans over the 10 year period in our sample. Our 10\% random sample consists of 48,709 firms. While a firm may have multiple loans from the same bank at a point in time, we aggregate loans at the firm-bank-quarter level which forms our unit of analysis. Thus a "loan" in this paper refers to a firm-bank pair.

Firms can enter and exit the sample during our sample period. The average tenure of a firm in our sample is 25.7 quarters (out of a possible of 41 quarters), with a median tenure of 26 quarters and 25th and 75th percentile of 14 and 41 quarters respectively. The distribution of bank credit across firms is highly skewed with top $10 \%$ of firms borrow $75.3 \%$ of total credit in the economy (Figure 1, top-left panel). The skewed nature of firm-size distribution is typical around the world. The dotted line in the top-left panel of Figure 1 shows that the cumulative distribution function of credit across banks is very similar to the CDF picture for firms. As with firms, the top $10 \%$ of banks dominate the credit market. 
There is a tendency for banks to merge over our sample period as well. There are 246 banks at the beginning of sample period and 214 banks by our sample's end. However, major bank mergers (in terms of size) happen before 2001Q4. Therefore, in order to keep a more consistent panel, we focus on the period 2001Q4 till 2009Q4 in our analysis. ${ }^{17}$ Since our core variation of interest occurs in mid-2000's, starting in 2001Q4 does not constrain our analysis.

The top-right panel in Figure 1 plots the total cumulative bank credit over time. There is a sharp increase in the growth of bank credit in 2004 followed by sudden stagnation in 2008 when the global financial crisis hits. One of our aims in this paper is to test the extent to which the boom in credit between 2004 and 2007 can be attributed to the rise in securitization. As such many of our tests focus on loans outstanding in 2004Q4, and follow them forward. ${ }^{18}$

Table II presents summary statistics for this set of firms. There are 29,848 firms taking out 67,838 loans in the fourth quarter of 2004. Since our methodology relies on firms with at least two banking relationships, Table II also presents summary statistics for this subset of firms. There are 15,697 such firms taking out 51,397 loans. While about half the total firms have multiple banking relationships, they represent $78 \%$ of total firm credit in the economy.

The average loan size is $€ 288,000$ and the average firm borrows a total of $€ 662,000$ from the banking sector. $1.9 \%$ of loans are in default as of 2004Q4. However, there is a sharp increase in defaults in 2008 and, by the end of 2009, almost $8 \%$ of loans are in default (Figure 1 bottom-left panel).

One of our key variables at bank level is a bank's exposure to real estate assets at the beginning of our sample period. This variable is constructed as the share of total bank loans that go to the real estate sector as of 2001Q1 (residential mortgages as well as loans to construction and real estate firms). The average exposure to real estate sector is $44 \%$ with a standard deviation of $15.7 \%$. The idea is to take into account the original stock of financial assets that directly or indirectly can be easily securitized. ${ }^{19}$

\footnotetext{
${ }^{17}$ If a bank is acquired by another bank, its loan portfolio shows up in the portfolio of the acquiring bank in our sample.

${ }^{18}$ There are 192 banks in 2004Q4.

${ }^{19}$ There was almost no securitization of loan to real estate developers in Spain. However, these loans turn
} 
Finally, we also have information at the loan level on total loan commitments, credit drawn, whether the loan is collateralized by an asset and the maturity of the loan. For a large subset of firms we also have information on total assets, sales and number of employees. Summary statistics of all these variables are presented in Table II.

\subsection{The Spanish Financial System}

Since securitization is largely limited to real estate loans, we discuss some key features of the Spanish mortgage industry. There is no counterpart to Freddie Mac and Fannie Mae in Spain. Consequently all mortgage loans are held by banks on their books in the beginning of our sample period when there is negligible securitization. This helps to explain the high share of real estate loans on banks' books in Spain. Another difference from the U.S. is that mortgage loans in Spain have full recourse to the borrower.

Banks in Spain can be classified in two broad categories: commercial banks and savings banks (or Cajas). Out of the 192 banks in 2004Q4 for which we have financial information, there are 46 savings banks representing $41.9 \%$ of total bank assets. Commercial banks are traditional banks (including foreign banks) that have shareholders as owners of the bank. Cajas on the other hand rely on a general assembly for governance, consisting of representatives of regional and municipal government, depositors representatives, and nongovernmental organizations (NGO) such as the catholic church, for instance. The general assembly elects a board of directors who look for a professional manager to run the banking business. Commercial banks profits can either be retained as reserves or pay out as dividends. For the Cajas, the profits are either retained or paid out as social dividend (i.e. to build and run educational facilities, libraries, sport facilities, pensioners clubs and so on where the Cajas operate). However, despite their differences in governance structures, both commercial banks and Cajas operate under the same regulatory framework and compete against each other in common markets.

Historically, Cajas have focused on households and engaged in providing mortgage and deposit facilities. Commercial banks, on the other hand, have been more dominant in lending into mortgages - often from the same bank - after sale of houses and then may be securitized. 
to the corporate sector. However there has been considerable convergence in the scope of the two types of banks since liberalization began around mid-seventies. Nonetheless, there remain differences between Cajas and commercial banks today with Cajas being more reliant on lending to real estate and household sectors.

\subsection{The Securitization Boom}

The global boom in market-mediated securitization is well known. Adrian and Shin (2010), Shivdasani and Wang (2011) and Ashcraft, Goldsmith-Pinkham and Vickery (2010) show that the issuance of non-GSE ABS and subprime MBS in the U.S. rose dramatically during 2004 to 2007. Securitization was driven by a series of global factors, such as global trade imbalances and accommodative monetary policy in the U.S. Furthermore, the rise in securitization was not limited to the U.S. Countries with characteristics similar to the U.S., such as large current account deficits and a housing boom, also saw a rise in the issuance of mortgage-backed securities. One such country was Spain. ${ }^{20}$

The lower-right panel in Figure 1 plots Spanish house prices over time. There is a sharp increase in the growth of house prices beginning in 2001 that runs until 2007 when the global recession kicks in. As with the U.S., the increase in house price appreciation is also associated with a rapid increase in the issuance of securitized real estate assets in Spain (though the boom in securitization came in 2005).

We use the term "securitization" for issuance of both covered bonds and asset-backed securities by banks in Spain. While the two securities differ in some aspects, they share the basic characteristic of allowing banks to access liquidity by pledging their real estate assets. We explain these two securities in more detail below.

Covered bonds are backed by a portfolio of mortgages with a loan-to-value ratio of at most $80 \%$. Moreover, banks can only issue covered bonds up to $80 \%$ of the total value of underlying mortgages. Finally, covered bonds also provide recourse to the issuing bank if needed. Thus covered bonds are heavily collateralized, and their sole purpose is the provision

\footnotetext{
${ }^{20}$ In the case of Spain, the majority of buyers were from other Euro Area countries (notably Germany) though they were also Asian (source: BIS, ECB and Bank of Spain).
} 
of liquidity. There is no capital advantage for issuing covered bonds and these bonds remain on a bank's balance sheet.

Asset backed securities (ABS) are issued by selling a portfolio of loans (usually mortgages). In Spain the originating bank is usually the servicer of loans as well. Thus one important difference between covered bonds and ABS is that ABS enable banks to transfer some credit risk out of their balance sheet.

However, even this distinction is not black and white. In certain cases, banks provide "credit enhancement" to an ABS, thus promising to absorb a certain percentage of the first losses in case of default. The accounting rules in Spain instructed banks to keep ABS on their balance sheets if they retain some component of credit risk. Since we do not know exactly whether a given ABS issuance is kept on the books or not, we cannot back out ABS issuance at the bank level from bank balance sheets alone. This is one of the reasons we use banks' holding of real estate assets as our main proxy for access to securitization.

Figure 2 plots the aggregate issuance of asset-backed securities and covered bonds in Spain over time. The top panel plots the annual flow, while the bottom panel shows the stock of securities issued. The issuance of securitized assets (whether ABS or covered) was close to negligible in the early 2000s. However, by 2004 issuances become substantial with over 50 billion Euros of securities issued every year. By 2008, the stock of securitized assets represents $29.9 \%$ of total bank credit.

\section{Securitization and the Lending Channel}

What does the securitization shock imply for Spanish banks? As highlighted earlier, 44\% of bank loans are granted to the real estate sector in Spain. Therefore, securitization (i.e. issuance of ABS and covered bonds) provides a novel opportunity for banks to use their real estate assets as collateral for wholesale financing. Securitization thus enhances a bank's access to liquidity, especially for banks with large loan portfolios backed by real estate assets.

Does greater access to liquidity encourage banks to make more loans to non-financial, non-real-estate firms? Relatedly, does enhanced liquidity lead banks to alter the terms at which they lend? We test such credit supply channel consequences of securitization. 


\subsection{Bank Level Evidence}

The effect of securitization is not uniform across all banks. Since securitization depends on real estate assets, banks with greater exposure to real estate assets are impacted more. This is confirmed in the top panel of Figure 3 that plots the change in securitized assets between 2004 and 2007 for a bank against its exposure to real estate assets in 2000. One can see that banks with greater exposure to real estate assets are able to securitize more assets.

This result is confirmed by columns (1) through (3) of Table III. Columns (1) and (2) present the bivariate relationship in un-weighted and weighted (by bank assets) regressions. The correlation between real estate exposure and securitization at the bank level is strong and highly significant. Since there is negligible securitization in the beginning of 2000s, an equivalent test for new securities issued is to regress the stock of securities issued by 2007 against initial real estate assets. This is done in column (3) and the correlation becomes even stronger.

Does increased access to liquidity due to securitization also lead banks to extend more credit? The bottom panel of Figure 3 presents preliminary evidence in this regard. It plots the change over 2004-07 in bank credit to non-real-estate sector against a bank's initial exposure to real estate. There is a strong and significant relationship between the two. This is further confirmed by column (4) of Table III. Column (5) shows that the same result holds if we replace real estate exposure with issuance of new asset-backed securities between 2004 and 2007.

Figure 3 and Table III provide preliminary evidence in favor of the presence of a credit channel at bank level. However, such evidence cannot be considered conclusive since banks with higher real estate exposure (our ex-ante proxy, instrument, for securitization) might be systematically different. For example, banks with higher exposure to real estate loans may be lending to firms that experience faster credit demand growth during the housing boom. If this were true, our bank level results would be spuriously driven by credit demand shocks, and could not be attributed to credit supply consequences of securitization. 


\subsection{Are Banks with Real-Estate Exposure Different?}

Table IV tests whether banks with high real estate exposure are systematically different. The top panel regresses various bank characteristics against banks' exposure to real estate assets and reports the coefficient on real estate exposure.

Banks with more real estate exposure as of 2000Q1 are similar to other banks in terms of profitability (return on assets), risk (non-performing loans) and capital ratio. However for reasons already highlighted, banks with real estate exposure are more likely to be Cajas (saving banks).

The middle panel tests whether firms borrowing from banks with high real estate exposure are systematically different. Since a firm may borrow from multiple banks, we take the average of initial real estate exposure for banks lending to a given firm. We find that firms borrowing from banks with greater real estate exposure are smaller in size along all dimensions - total assets, bank credit and sales. These firms also have higher tangible assets to total assets ratio, and are less likely to borrow short term.

The bottom panel tests if loan level outcomes as of 2000 differ for banks with greater real estate exposure. While there is no difference in default rates, loans from banks with more real estate exposure are smaller on average, more likely to be collateralized and more likely to have longer maturities. The right-lower panel repeats these loan level tests, but includes firm fixed effects to focus only on within-firm variation. The loan size result goes away, showing that conditional on lending to the same firm, loan amount does not differ across banks with differential real estate exposure.

The picture painted by Table IV reveals that banks with more real estate loans as a fraction of their total loan portfolio do not differ by profitability, risk, or capital, but are more likely to be Cajas. In terms of their portfolio, real-estate exposed banks lend to smaller firms that have more tangible assets and rely on longer term financing. Consequently, loans of real-estate dependent banks are more likely to be collateralized and have longer maturity. 


\section{$5 \quad$ Estimating the Aggregate Lending Channel}

Since firms borrowing from real estate exposed banks are quite different, there is a legitimate concern that the increase in credit by these banks between 2004 and 2007 is not driven by securitization, but by stronger credit demand from the type of firms borrowing from these banks. Even if the firms borrowing from real estate exposed banks were not different on observables, one could worry about differences along unobservable dimensions. However, as Section II explained, we can address such concern by using firms fixed effects to fully absorb changes in credit demand (fundamentals) at the firm level.

\subsection{Local Lending Channel Estimates}

We regress change in credit from 2004Q4 to 2007Q4 against a lender's initial exposure to real estate assets. We use real estate loan share as of 2000Q1 as our main proxy for banks' exposure to securitization - rather than a direct measure of securitized assets - for three reasons.

First, data on securitized assets is not available for some banks whereas real estate exposure is available for all banks. Second, as we mentioned in the previous section, securitized assets are not always kept on banks' books. Therefore, it is difficult to keep an accurate count of securitized assets. However, we have already seen in Table II, banks with more real estate loans issue more covered bonds and ABS (to the extent observed). Third, and perhaps most importantly, what matters most for credit channel is the ability and expectation of access to liquidity. ${ }^{21}$ Even for a bank that has not yet securitized many of its assets, the knowledge that it has securitizable assets and hence access to liquidity could make it extend new credit. ${ }^{22}$

Column (1) of Table V estimates equation (1) without firm fixed effects. In line with the bank-level results of Figure 3 and Table II, there is a strong correlation between business loan

\footnotetext{
${ }^{21}$ Bank credit supply (at $t=0$ in a model à la Diamond and Rajan (2006) or Allen and Gale (2007)) depends on the expectation of accessing future liquidity ( $t=1$ in these models); therefore it is the potential access to liquidity (via securitization) that matters most for credit supply rather than actual liquidity (at $t=1$ via securitization activity).

${ }^{22}$ Nonetheless our results are robust to using securitized assets by 2007 as our main right hand side variable.
} 
growth and a bank's initial exposure to real estate assets. Can we attribute this correlation to a credit supply effect? Since we need firm-fixed effects to answer this question, we limit ourselves to firms with multiple banking relationships as of 2004Q4. Column (2) restricts sample to such firms with results similar to column(1).

Column (3) adds firm fixed effects. The coefficient on bank real estate exposure $(0.386)$ implies that a one standard deviation increase in real estate exposure generates a 6.1 percentage points higher growth in credit supply. This is more than a doubling of the average loan-level credit growth rate of 5.7\% between 2004Q4 and 2007Q4. ${ }^{23}$

Since real estate exposed banks tend to grant longer term and more collateralized loans, there may be a residual concern that our results are driven by differences in the types of loans extended by real estate exposed banks. For example, perhaps credit boom was driven by greater demand for longer term loans which happen to be the specialization of real estate exposed banks. Column (4) therefore controls for a loan's collateralization rate and maturity as of 2004Q4 as well as changes in these variables between 2004Q4 and 2007Q4. There is no appreciable change in the coefficient of interest.

Finally, we know that savings banks (Cajas) are more likely to have high real estate exposure. Could our results thus far be described as a Cajas phenomenon? We address this issue in column(5) by including bank-type interacted with firm fixed effects, where bank-type is either "commercial" or "Cajas". The regression thus forces comparison across loans of the same firm and from the same bank-type. As results show, our coefficient of interest is even stronger than before.

Columns (2) through (5) go through a strong battery of tests to isolate the supply side transmission channel driven by a bank's exposure to real estate. ${ }^{24}$ Firm fixed effects, loan level controls, and bank-type interacted with firms fixed effects control for credit demand

\footnotetext{
${ }^{23}$ This should not be confused with the overall growth in credit at the firm level, which is $21.4 \%$. Loanlevel credit growth is smaller as a firm can stop borrowing from a bank between 2004 and 2007, and start borrowing from a different bank.

${ }^{24}$ Other robustness tests we have run are: double cluster of standard errors at both firm and bank level; controlling for other key bank characteristics such as capital, NPLs, size, profits and liquidity; controlling for the average real estate exposure of other banks lending to the same firm; expanding to all firms including loans to real estate firms; and, controlling for firm observables in firm level regressions where firm fixed effects are not possible (this only for the aggregate channel). Results are very similar.
} 
shocks in a nonparametric way. The strong power of controls can be gauged from the fact that R-sq goes to 0.003 in column (2) to 0.7 in Column(5) without any decrease in the coefficients' magnitude. As Altonji et al. (2005) point out, the persistence of a coefficient despite a substantial increase in regression R-sq due to controls provides strong support for exogeneity of the right hand side variable of interest.

Finally, there may be a remaining concern that our results are driven by some pre-existing trends in data. Column (6) tests for this by repeating our core specification over the period 2001Q4 to 2004Q4. The estimated coefficient turns out to be negative and is statistically indifferent from zero.

A downside of the dependent variable we have used thus far (the "intensive margin") is that we cannot compute change in loan amount for loans that are dropped before $2007 \mathrm{Q} 4$. In order to take such "dropped loans" into account, we construct an indicator variable that is 1 if a loan exists in 2004Q4 but not in 2007Q4, and 0 if it exists in both quarters.

Column (7) repeats our core specification using "loan dropped" as dependent variable (i.e., the "extensive margin of dropped loans"). The number of loans increases in column (7) from 32,647 to 51,397 because of the inclusion of all outstanding loans in 2004Q4 regardless of their status in 2007Q4. Consistent with our earlier results, banks with higher real estate exposure are less likely to drop a loan. Column (8) uses a Tobit specification to combine the "intensive margin" effect of column (3) and the "extensive margin" result of column (7). The combined effect of the two margins makes the overall impact in the credit channel even stronger.

\subsection{Aggregate Lending Channel Estimates}

The results thus far highlight a strong credit supply channel effect driven by exposure to real estate assets. However, as we emphasized in the Introduction and Section 2, these results are incomplete as they do not incorporate firm-level adjustments in response to credit supply shocks from banks. This section addresses this limitation by implementing the empirical strategy highlighted in Section 2. 
Column (9) presents the OLS (and potentially biased) estimate of firm-level credit channel coefficient. The coefficient is close to zero and precisely estimated. The unbiased estimate of firm level credit channel is given by equation (3), which adjusts the coefficient in column (9) to take into account endogenous matching of firms with banks. Since the adjustment term depends on the differences between loan level OLS and fixed effect estimate, it is going to have a small effect in our case. ${ }^{25}$ The adjustment term is equal to $(0.404-0.386) * 0.025 / 0.0123$, i.e. 0.037. The unbiased firm level credit channel effect is thus equal to $0.023-0.043=-0.020$. It turns out that despite a very strong credit supply channel effect at the bank level, the net impact is close to zero! ${ }^{26}$

Our result thus highlights the importance of incorporating firm level adjustments in credit channel estimates. A simple correlation - or even causation - between bank credit extension and bank liquidity shocks can be highly misleading. The speed at which firm-level borrowing adjusts also points towards a dynamic banking system where borrowing relationships are created and destroyed at regular frequency. Consistent with this view, we find that about 45 percent of firms during our sample period break away an existing banking relationship and start a new banking relationship with a different bank afterwards. Similarly, 75 percent of all firms borrow from at least two banks during our sample period.

\subsection{Quarter by Quarter Estimates}

The regressions in Table V focused on the 2004Q4 to 2007Q4 period, which is the heart of credit boom in Spain. Since the underlying data are quarterly and span a much longer time horizon, we can replicate our estimates at a quarterly frequency over the entire period.

We anchor 2004Q4 as our reference quarter, and use $\Delta \log ($ credit) between quarter $t$ and 2004Q4 as dependent variable for each quarter $t$ from 2001Q4 to 2009Q4. We estimate the OLS and FE regressions corresponding to columns (2) and (3) of table V respectively and plot the corresponding coefficients on bank exposure to real estate in the top panel of Figure 4. These coefficients capture the evolution of loan-level credit channel in Spain.

\footnotetext{
${ }^{25}$ Our simulation exercise in section 1 shows that in general these adjustments can have a significant impact.

${ }^{26}$ Non-bank sources are unlikely to play a significant role in our analysis since the net impact is close to zero with only bank sources alone.
} 
Both OLS and FE estimates are close to zero until 2004Q4 and statistically not different from zero. ${ }^{27}$ Thus the credit channel documented in Table $\mathrm{V}$ is not driven by any pre-existing trend. There is no differential growth in credit prior to 2004Q4 for loans granted by banks with greater real estate exposure.

This finding also suggests that our earlier results are not driven by a boom in house prices alone. As Figure 1 shows, the growth in house prices was as strong during the 2001-04 period as the 2004-07 period. If the credit channel effect in Table V was driven by real estate exposed banks' loan assets appreciating in value, we should see a similar effect over 2001 to 2004. The fact that we do not suggests that the credit channel effect is driven by the boom in securitization that kicks into high gear between 2004 and 2007.

Our results indicate that once securitization market is strong enough in terms of volume and is sustained over a long enough period, banks begin to rely on the newly found source of liquidity and start lending against it. The credit channel effect of securitization builds gradually over time until 2008, when the private market for securitization shuts down. Once the global financial crisis begins in fall of 2008, the credit channel in Spain turns negative: Banks with greater ex-ante exposure to real estate assets start contracting credit at a faster pace.

The top panel uses log change in loan amount outstanding as dependent variable. The lower panel replicates the analysis but uses log change in total commitment amount as dependent variable. The coefficient estimates are similar to the top panel with one important difference. The post-2008 reversal in credit channel is stronger with loan commitment than loan outstanding. This difference reflects a stronger contraction in the supply of credit by real-estate exposed banks through loan commitments. The differential impact for outstanding loans is smaller because the drawn to commitment ratio rises faster for banks with more real estate exposure. ${ }^{28}$

The post-2008 reversal in bank lending channel at the loan level takes place despite massive European Central Bank (ECB) intervention in the securitization market (banks massively borrowed in the ECB/Eurosystem against their collateral). As Figure 2 makes

\footnotetext{
${ }^{27}$ Standard errors are not reported for brevity, but are similar to those shown in corresponding tables.

${ }^{28}$ This is similar to the finding in U.S. by Ivashina and Sharfstein (2009).
} 
clear, the flow of asset-backed securities issued by Spanish banks in 2008 and beyond is almost entirely driven by the interest of the banks to build up a portfolio of securities that can be used as collateral for liquidity through the ECB. The private market for securitized assets had pretty much evaporated by then. ${ }^{29}$ Our result thus illustrates that banks with greater dependence on securitization start to cut back credit drastically - a credit crunch when private securitization market dries up. ${ }^{30}$ However, the net impact of this cut is not as strong. As Figure 5 shows, firm level adjustment mutes the overall impact of bank-specific cuts in credit during 2008-09.

The OLS and FE estimates track each other quite closely in Figure 4. Since the FE estimate absorbs credit demand shocks at the firm-level, the compliance between OLS and FE estimates show that credit demand shocks during our sample period are largely orthogonal to credit supply shocks driven by exposure to real estate assets.

Figure 5 replicates firm-level OLS estimate of column (9) in Table V, but replaces the dependent variable with log change in firm credit between quarter $t$ and 2004Q4. As in Figure 4, we plot the OLS coefficient separately for each $t$ from 2001Q4 to 2009Q4. The top panel uses log change in firm credit outstanding as dependent variable, while the lower panel uses log change in total loan commitment for a firm as dependent variable.

The dotted line in Figure 5 plots firm-level OLS coefficients, while the solid line reflects corresponding bias-corrected coefficients implied by equation (3). Since loan-level OLS and FE estimates in Figure 4 are close to each other, OLS and bias-corrected coefficients do not differ significantly in Figure 5 either. The bias-corrected coefficients in Figure 5 reflect the net impact of credit channel over time. As in the case of 2004Q4-2007Q7 period, net impact is close to zero throughout our sample period.

\footnotetext{
${ }^{29}$ Source: Dealogic, ECB and Bank of Spain.

${ }^{30}$ See e.g. Diamond and Rajan (2011), Shin (2009), Shleifer and Visnhy (2010), Allen and Gale (2007).
} 


\section{Credit Terms, Real Outcomes and Extensive Margin Lending}

\subsection{Local Lending Channel and Credit Terms}

The local lending channel, i.e. loan-level impact of credit supply channel on credit quantity, is undone by firm level adjustments for firms with multiple borrowing relationships. But what about credit terms? Greater willingness by banks to extend credit supply could lead to greater competition, hence putting downward pressure on credit terms.

While we do not observe interest rates, we know the fraction of loan commitment that is drawn down by a borrower as well as loan maturity and collateralization rate. Changes in loan draw-down rate (drawn credit over total commitment) during the credit boom gives us useful information on the otherwise unobserved terms of credit (such as covenants and interest rates). This idea is based on a revealed preference argument. As banks compete more aggressively for a firm's business, the firm should prefer to draw down more aggressively from the bank with better loan terms.

Columns (1) through (3) in Table VI test if the draw-down ratio goes up faster during 2004Q4 to 2007Q4 for banks with greater exposure to real estate. Column (1) runs our core specification on data restricted to multiple relationship firms as of 2004Q4. There is a strong effect of bank real estate exposure on growth in drawn-down rate. A one standard deviation increase in bank's real estate exposure increases the drawn-down ratio by 1.33 percentage points.

The increase in drawn-down ratio could have resulted from declining loan commitments. However, as we have already seen in Figure 4, banks with greater real estate exposure are increasing their loan commitments at a faster pace during 2004-07 period. The increase in draw-down ratio despite faster growth in loan commitments from real-estate-exposed banks, hence, points towards better loan terms offered by these banks.

Column (2) shows that the increase in drawn to commitment ratio is not driven by real estate exposed banks making different types of loans. For example, if real estate exposed banks granted more shorter maturity loans during the time period, such loans are naturally 
going to have higher drawn to commitment ratio. Column (2) adds loan maturity and collateralization rate as of 2004Q4, as well as change in these variables between 2004Q4 and 2007Q4 as controls. There is no change in our coefficient of interest. Column (3) further adds firm fixed effects, thus absorbing shocks at the firm level and isolating credit-supply-driven changes in loan terms. Our coefficient of interest increases slightly.

A direct measure of credit terms in our data is the fraction of loan that is collateralized. If credit terms are relaxed over 2004-2007 by banks with more real estate exposure, then we would expect rates of collateralization to go down more for these banks. Columns (4) to (6) show that this is the case, although statistical significance depends on the specification chosen. However, once we control for loan maturity in 2004Q4 and change in loan maturity between 2004Q4 and 2007Q4, the drop in collateralization rate is stronger and significant for banks with more real estate exposure. This is consistent with our earlier interpretation that securitization leads to more favorable credit terms for borrowers.

The inclusion of controls for loan maturity is necessary when testing for differences in collateralization change for two reasons. First, as we saw in Table IV, real estate exposed banks are more likely to have longer maturity loans which naturally have higher rates of collateralization. Second, and more importantly, the change in propensity to make longer term loans is also stronger for banks with real estate exposure. This is shown in columns (7) though (9) of Table VI. Hence, as done in column (5), it is important to control for loan maturity and changes in loan maturity when comparing differences in collateralization rates.

Figure 6 plot the quarter-by-quarter OLS and FE coefficients for drawn-to-commitment and collateralization rate. The sharp increase in drawn to commitment ratio for real estate exposed banks kicks in around 2005. Before 2005 there is no differential effect. Similar, though a bit weaker, results hold for collateralization rate as well.

\subsection{Aggregate Lending Channel, Credit Terms and Real Out- comes}

Our methodology for estimating the net impact of credit channel at firm level (i.e. the aggregate lending channel) can be applied to any outcome where we can estimate OLS and 
FE regressions separately at loan level. Since we have done so for changes in drawn-tocommitment ratio, maturity and collateralization, we can estimate their bias-corrected firm level impact as well. Columns (1) though (3) in Table VII show that changes in all three of these outcomes are significant at firm level.

Thus while loan level impact in credit quantity is undone by firm-level adjustments, the same is not true for credit terms! As banks with real estate exposure become more willing to extend credit, there is greater competition for a given firm's overall debt capacity. The competition results in borrowing firms receiving softer, more favorable credit terms.

Despite the zero impact of securitization-induced credit supply channel on the quantity of credit, there could be positive firm real effects through the induced lower price of credit. Columns (4) through (6) of Table VII show that firms borrowing from banks with greater real estate exposure do not experience any differential change in propensity to default, sales or number of employees. There is thus no evidence of any appreciable impact on real firm outcomes over the period 2004 to 2007 due to securitization. Hence, despite of large effects at the bank-firm level, the crowding-out completely mitigates these effects for firm real outcomes.

\subsection{Extending Credit to New Clients}

So far our core analysis was based on loans outstanding in 2004Q4, which were followed forward in time. Banks with greater exposure to real estate assets increased their credit supply for existing loans as securitization kicked in. While this credit channel is counter-balanced by crowding out adjustments at firm level, the question remains whether securitization led to a net increase in credit for new borrowers. A shift in the supply of bank credit should make banks more willing to lend to riskier firms on the extensive margin (see e.g. Shin, 2009). These firms may have been denied credit in the past, but with securitization expanding the supply of credit, they have a better chance of getting a loan.

Table VIII tests whether banks with greater real estate exposure lend more to new clients on the extensive margin. We define "new credit" as credit given to first-time clients between 2004Q4 and 2007Q4 and regress the log of total new credit against a bank's initial exposure 
to real estate assets. We find that banks more exposed ex-ante to real estate are significantly more likely to make loans to new clients on the extensive margin. Column (2) replaces new credit drawn with new total credit commitments and gets similar results.

Column (3) normalizes new credit outstanding by total assets of the bank. The estimated coefficient implies that a one standard deviation increase in real estate exposure is associated with the bank lending out 10.4 percent more of its assets as credit to new clients. New bank clients can be of two types: firms that never borrowed from any bank in the past, and firms that start borrowing from the given bank for the first time after 2004Q4. Column (4) splits these two types by only focusing on lending to firms that never borrowed from any bank in the past. The coefficient drop to 0.38 from 0.665 , showing that more than half of our extensive margin result is driven by lending to firms that did not borrow from any bank in the past.

Column (5) shows that new credit driven by exposure to real estate assets is significantly more likely to default by the end of 2009. We regress the 2009Q4 default rate of new credit against initial bank exposure to real estate. The estimated coefficient is statistically significant and economically large in magnitude. A one standard deviation increase in bank exposure to real estate is associated with 1.03 percentage point increase in default rate for new credit. ${ }^{31}$

Figure 7 plots the quarter-by-quarter estimates of columns (3) and (4). The dependent variable is new credit granted between 2004Q4 and quarter $t$, with $t$ going from 2005Q1 to 2009Q4. The differential growth in new credit continues until 2008, before collapsing as the financial crisis kicks in.

The extensive margin regressions are run at bank level and hence suffer from the usual criticism that unobserved credit demand shocks might contaminate our coefficients. We cannot use our firm fixed effects approach to tease out the supply-driven effect anymore. However, our earlier results are useful for interpreting causality of our extensive margin results.

\footnotetext{
${ }^{31}$ The power gets weak if we try to split defaults by borrowers that did not borrow from any bank in the past, and borrowers that are first-time borrowers with the said bank. However, the coefficient on bank RE exposure is positive for both these groups.
} 
The estimated covariance between credit demand and credit supply shocks for firms borrowing from multiple banks in 2004Q4 was close to zero. It is reasonable to assume that similar correlation holds on the extensive margin as well. For instance, given the estimated covariance term for existing borrowers, it is unlikely that credit demand from future potential clients will go up disproportionately more for firms that tend to apply for loans with realestate-exposed banks. We thus feel confident in interpreting the coefficients in Table VIII as being driven by supply-side shocks as well.

\section{Concluding Remarks}

As the securitization market threatened to dry up and banks suffered major losses, governments all over the world fretted about the possibility of banks transmitting their adverse shocks through a credit crunch to the rest of the economy. Many governments and central banks (including the U.S. and Europe) intervened in the banking sector with large sums of money to try to prevent any amplification of the downturn through the banking system. Such fears are common in almost all instances of financial downturns. In fact, even in normal times, policy makers set monetary and credit policies with one eye open towards possible ramifications for the bank transmission channel.

However, despite the importance attached to bank transmission channels in real life, we lack a basic set of tools that policy makers can use in real time for understanding the impact of transmission mechanisms. The goal of this paper was two-fold: (i) to introduce a formal procedure that takes an aggregate approach towards transmission mechanisms by taking into account equilibrium effects at the firm level and (ii) to identify, by using of our methodology, the transmission consequences of mortgage securitization.

It would be imprudent to suggest that bank transmission channel is always important, or that it is never relevant. The nature and magnitude of transmission channel is likely to depend on the particular environment and episode in question. Since each situation is different, we need a set of tools - rather than a pre-determined answer - to guide us in the real world. 
The methodology introduced in this paper can serve as one of the tools used by the new supervisory agencies both in U.S. and Europe in charge of monitoring systematic risk. There are three main advantages that our methodology provides in this regard. First, it can be applied to a range of different situations where the shock affecting the banking sector may not be securitization necessarily. As long as one can identify cross-bank heterogeneity in exposure to possible banking sector shocks (e.g. some form of financial innovation, bank runs, specific industry or country exposure), our methodology can be utilized to separate supply-side effects from demand and to estimate local as well as aggregate lending channels.

Second, our methodology can be used to identify both the quantity and price effects of shifts in the supply of bank credit. Credit booms are often associated with more favorable, softer credit terms for borrowers, such as lower collateral requirements, decline in credit spreads, or more "covenant light" loans. Our methodology provides a formal mechanism for understanding the extent to which such changes in the price of credit are driven by expansion on the supply side.

The methodology introduced in this paper goes beyond estimating whether banks per se transmit the liquidity shocks they face. It takes into account equilibrium adjustments that firms may undertake in response to any shocks from the banking system. As our results from Spain illustrate, this latter step is critical: without it one could have incorrectly concluded that securitization had a big impact on credit quantity for all firms. Instead we find that the aggregate impact of securitization in terms of credit quantity was limited to new borrowers, while credit terms were relaxed for all borrowers.

Given the importance of securitization over the last decade (including the crisis) and, in general, the possible role of financial innovation in promoting excessive credit creation and risk taking for crises in the past (emphasized by a number of economic historians), our results on the impact of securitization on bank credit supply and risk are of independent interest. More recently, securitization has been associated with lax lending and excessive credit creation in mortgage markets during the 2000's (Keys et al (2010) and Mian and Sufi (2009). 
Did these problems also spill over to non-financial corporate sector through bank transmission channel? Our analysis provides some mixed results in this regard. For firms that already had strong access to the banking sector, securitization did not lead to an increase in quantity of credit. There is no evidence that securitization had an appreciable effect on real firm outcomes either.

Securitization did, however, lead to more relaxed credit terms for all firms. There is also a strong effect of securitization on credit to new borrowers. Securitization enabled banks with real estate assets to expand credit supply on the extensive margin. The new loans are riskier with greater propensity to default during the crisis, suggesting that bank's relaxed their screening rules in order to expand credit supply. 


\section{References}

Allen, Franklin and Douglas Gale (2007). Understanding Financial Crises, Clarendon Lecture Series in Finance. Oxford: Oxford University Press.

Altonji, Joseph G; Todd E. Elder, and Christopher R. Taber. 2005. "Selection on Observed and Unobserved Variables: Assessing the Effectiveness of Catholic Schools", Journal of Political Economy. Volume 113, Issue 1, Page 151-184, Feb.

Ashcraft, Adam. 2005. "Are Banks Really Special? New Evidence from the FDIC-Induced Failure of Healthy Banks." American Economic Review, 95(5).

Ashcraft, Adam; Paul Goldsmith-Pinkham and James Vickery. 2010. "MBS Ratings and the Mortgage Credit Boom", Federal Reserve Bank of New York Staff Report No. 449.

Adrian, Tobias and Hyun Song Shin. 2010. "Money, Liquidity and Monetary Policy", American Economic Review.

Bernanke, Ben. 1983. "Non monetary Effects of the Financial Crisis in the Propagation of the Great Depression." The American Economic Review, 73(3): 257-276.

Bordo, Michael, 2009. "An Historical Perspective on The Crisis Of 2007-2008”, NBER Working Paper 14569.

Broecker, Thorsten. 1990. "Credit Worthiness Tests and Interbank Competition", Econometrica 58, 429-452.

Caballero, Ricardo J., Takeo Hoshi, and Anil K. Kashyap. 2008. "Zombie Lending and Depressed Restructuring in Japan." American Economic Review, 98(5): 1943-77.

Calomiris, Charles W. 2008. "The Subprime Turmoil: What's Old, What's New and What's Next," Jackson Hole Conference, Wyoming, October 2nd, 2008.

Dell'Ariccia, Giovanni and Robert Marquez. 2006. "Lending Booms and Lending Standards", Journal of Finance 61(5), 2511-2546.

Diamond, Douglas and Raghuram Rajan. 2000. "A Theory of Bank Capital," Journal of Finance, vol 55(6), 2431-2465.

Diamond, Douglas and Raghuram Rajan. 2001. "Liquidity Risk, Liquidity Creation and Financial Fragility: A Theory of Banking," Journal of Political Economy, vol 109(2), 287327.

Diamond, Douglas and Raghuram Rajan. 2006. "Money in a Theory of Banking," American Economic Review, 96, (1), 30-53.

Diamond, Douglas and Raghuram Rajan. 2011. "Fear of Fire Sales, Illiquidity Seeking, and Credit Freezes," Quarterly Journal of Economics, forthcoming. 
Djankov, Simeon, Caralee McLiesh, and Andrei Shleifer. 2007. "Private Credit in 129 Countries," Journal of Financial Economics, May.

Faulkender, Michael, and Mitchell Petersen. 2006. "Does the Source of Capital Affect Capital Structure?" Review of Financial Studies 19, 45-79.

Gertler, Mark and Nobuhiro Kiyotaki. 2010. "Financial Intermediation and Credit Policy in Business Cycle Analysis." Handbook of Monetary Economics.

Goldstein, Itay and Ady Pauzner. 2005. "Demand Deposit Contracts and the Probability of Bank Runs," Journal of Finance, vol. 60(3), pp. 1293-1328.

Hanson, Samuel; Anil Kashyap and Jeremy Stein. 2010. "A Macroprudential Approach to Financial Regulation", Journal of Economic Perspectives.

Ivashina, Victoria and David Scharfstein, 2009, "Bank Lending during the Financial Crisis of 2008," Journal of Financial Economics, forthcoming.

Iyer, Rajkamal and José-Luis Peydró. 2011. "Interbank Contagion at Work: Evidence from a Natural Experiment," Review of Financial Studies, 24, 1337-77.

Jiménez, Gabriel, Steven Ongena, José-Luis Peydró, and Jesús Saurina. Forthcoming. "Credit Supply and Monetary Policy: Identifying the Bank Balance-Sheet Channel with Loan Applications," American Economic Review.

Jiménez, Gabriel, Steven Ongena, José-Luis Peydró, and Jesús Saurina. 2011. "Hazardous Times for Monetary Policy: What do Twenty-Three Million Bank Loans Say About the Effects of Monetary Policy on Credit Risk?," ECB.

Kashyap, Anil K. and Jeremy Stein. 2000. "What do a Million Observations on Banks Say About the Transmission of Monetary Policy." American Economic Review, 90(3): 407-428.

Keys, Ben; Tanmoy Mukherjee; Amit Seru and Vikrant Vig. 2010. "Did Securitization Lead to Lax Screening: Evidence from Subprime Loans 2001-2006", Quarterly Journal of Economics, 125(1).

Kindleberger, Charles P. 1978. Manias, Panics, and Crashes: A History of Financial Crises, New York: Basic Books.

Khwaja, Asim I. and Atif Mian, 2008. "Tracing The Impact of Bank Liquidity Shocks", American Economic Review, September 2008.

Kohn, Donald. 2009. "Monetary Policy Research and the Financial Crisis: Strengths and Shortcomings", Speech at the Federal Reserve Conference on Key Developments in Monetary Policy, Washington, D.C., October 9, 2009. (http://www.federalreserve.gov/newsevents/speech/kohn20091009a.htm)

Leary, Mark. 2009. "Bank Loan Supply, Lender Choice and Corporate Capital Structure," Journal of Finance 64, 1143-85. 
Loutskina, Elena and Philip Strahan, 2009. "Securitization and the declining impact of bank financial condition on loan supply: Evidence from mortgage originations", Journal of Finance, 64(2), 861-922.

Maddaloni, Angela and José-Luis Peydró. 2011. "Bank Risk-Taking, Securitization, Supervision, and Low Interest Rates: Evidence from the Euro Area and U.S. Lending Standards," Review of Financial Studies, 24, 2121-65.

Mian, Atif R. and Sufi, Amir, 2009. "The Consequences of Mortgage Credit Expansion: Evidence from the U.S. Mortgage Default Crisis", Quarterly Journal of Economics 124.

Morrison, Alan and Lucy White. 2005. "Crises and Capital Requirements in Banking." American Economic Review 95, no. 5, 1548-1572.

Mulligan, Casey B. 2008. "An Economy You Can Bank On”, The New York Times, Op-ed, October 9 .

Paravisini, Daniel. 2008. "Local Bank Financial Constraints and Firm Access to External Finance." The Journal of Finance, 63, 2161-93..

Peek, Joe and Eric S. Rosengren. 2000. "Collateral Damage: Effects of the Japanese Bank Crisis on Real Activity in the United States." American Economic Review, 90(1): 30-45.

Petersen, Mitchell, and Raghuram Rajan. 1994. "The Benefits of Lending Relationships: Evidence from Small-Business Data," Journal of Finance 49, 3-37.

Rice, Tara, and Philip Strahan. 2010. "Does Credit Competition Affect Small-Firm Finance?" Journal of Finance, June.

Shin, Hyun. 2009. "Securitisation and Financial Stability," Economic Journal, 119, 309 332.

Shivdasani, Anil and Yihui Wang. 2011. "Did Structured Credit Fuel the LBO Boom?" Journal of Finance, forthoming.

Shleifer, Andrei and Robert Vishny. 2010. "Unstable Banking," Journal of Financial Economics, September.

Stein, Jeremy. 1998. "An Adverse Selection Model of Bank Asset and Liability Management with Implications for the Transmission of Monetary Policy," RAND Journal of Economics $29,466-86$.

Stein, Jeremy. 2011. "Monetary Policy as Financial-Stability Regulation," Quarterly Journal of Economics, forthcoming.

Stiglitz, Joseph and Andrew Weiss. 1981. "Credit Rationing in Markets with Imperfect Information," American Economic Review 71, 393-410. 
Trichet, Jean-Claude. 2009. "Systemic Risk", Speech in Cambridge University. (http://www.ecb.int/press/key/date/2009/html/sp091210_1.en.html)

White, Eugene N., Editor 1996. Stock Market Crashes and Speculative Manias, Cheltenham, UK: Edward Elgar. 
Figure 1

\section{Credit and Housing Market in Spain}
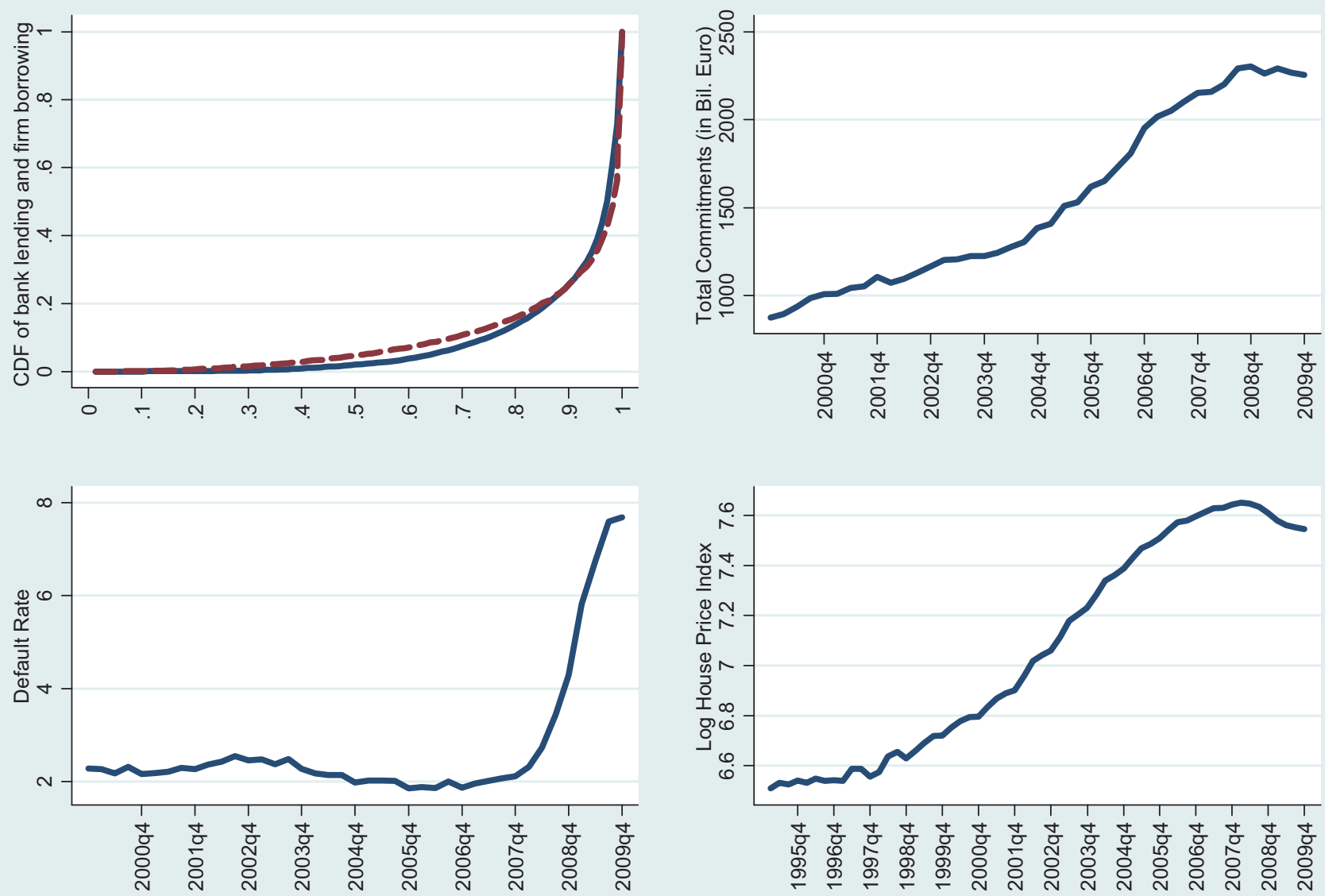

The top-left panel plots the cumulative distribution function for firm-level bank debt (solid line), and bank-level total lending (dashed line). The top-right panel plots total bank loan commitments to the non-real estate and non-financial sector in Spain. The bottom-left panel plots default rate for Spanish firms over time (limited to non-real estate and non-financial sector). The bottom-right panel plots the log of residential house price index in Spain. 
Figure 2

ABS And Covered Bond Issuance In Spain

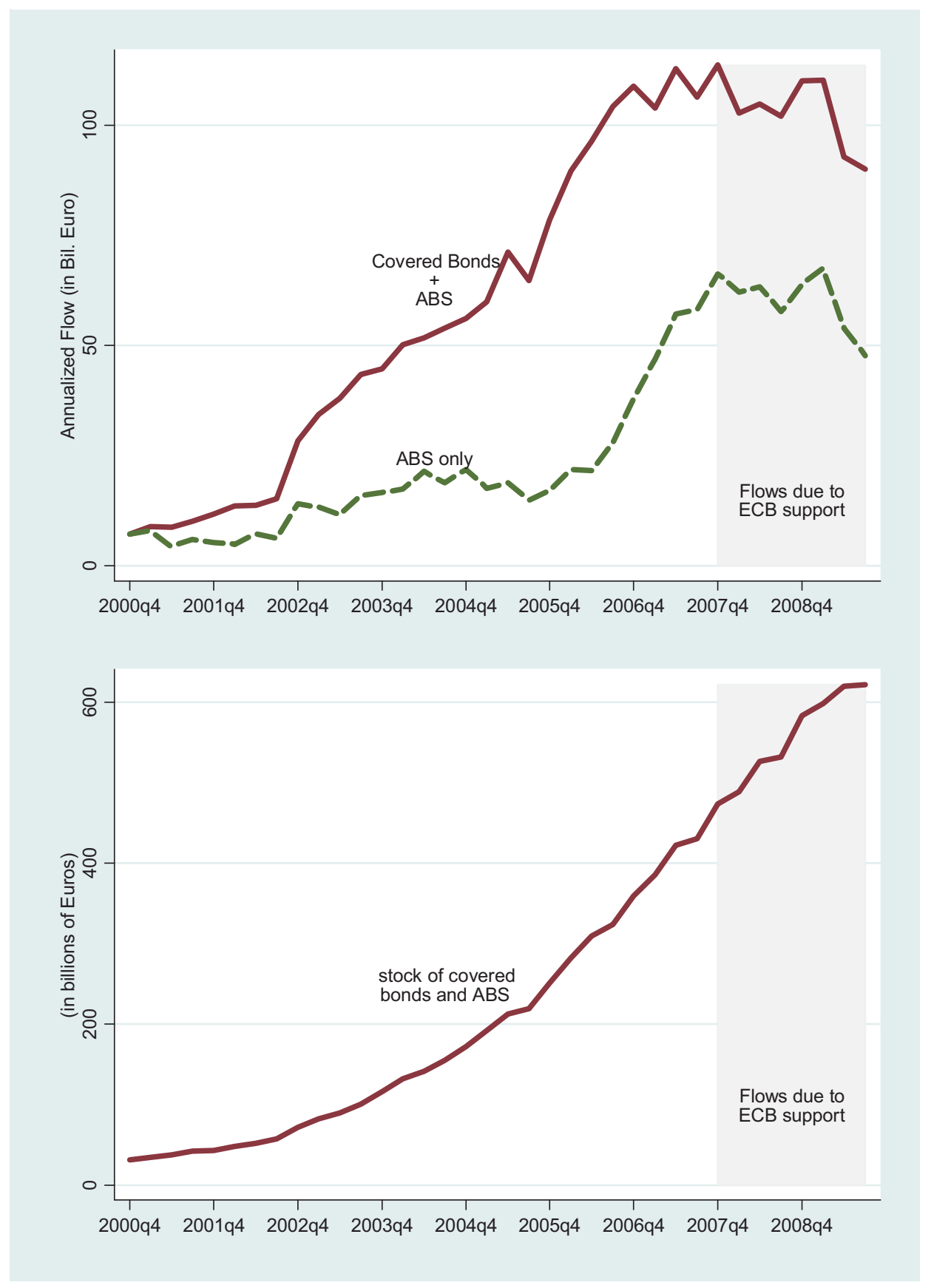

The top panel plots the annual flow of asset-backed securities issued in Spain. The solid line includes both $A B S$ and covered bond issuance, while the dotted line only includes ABS issuance. The shaded area post 2007 represents ABS issuance that was put as collateral with the ECB for liquidity support. The bottom panel plots the stock of $A B S$ and covered bonds over time in Spain. 
Figure 3

Securitization, Bank Credit and Banks' Exposure to Real Estate
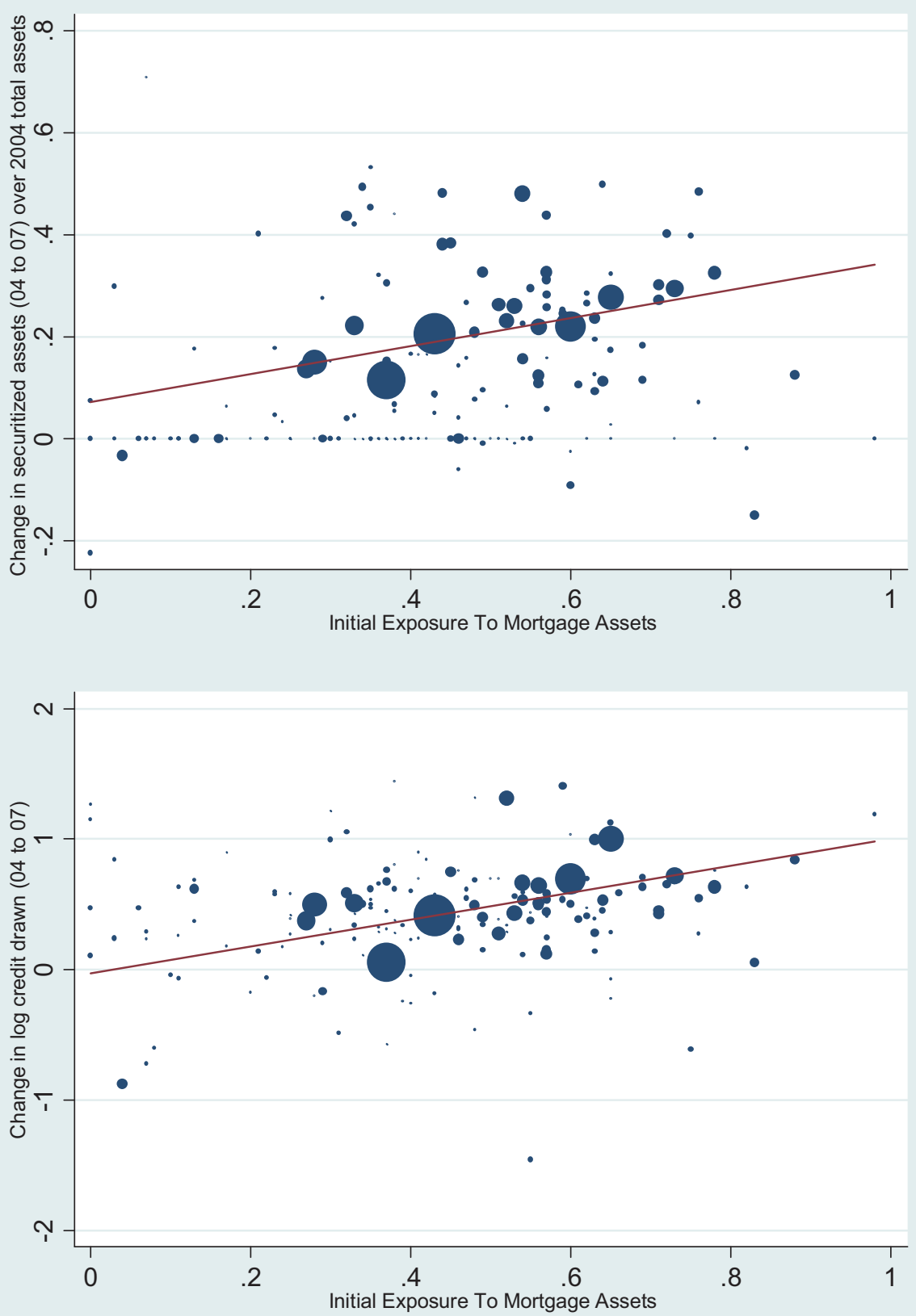

The top panel plots change in securitized assets (covered bonds and ABS) at the bank-level between 2004 and 2007 (normalized by bank total assets in 2004) against initial exposure to mortgage assets in 2000. Exposure to mortgage assets is defined as the share of total bank loans that go to the real estate sector. The size of each bank-level observation in the plot is proportional to bank size. The bottom panel plots the 2004 to 2007 change in log bank credit to non-real estate and non-financial sector against banks initial exposure to mortgage assets. 
Figure 4

Loan-Level Credit Channel Coefficients By Quarter
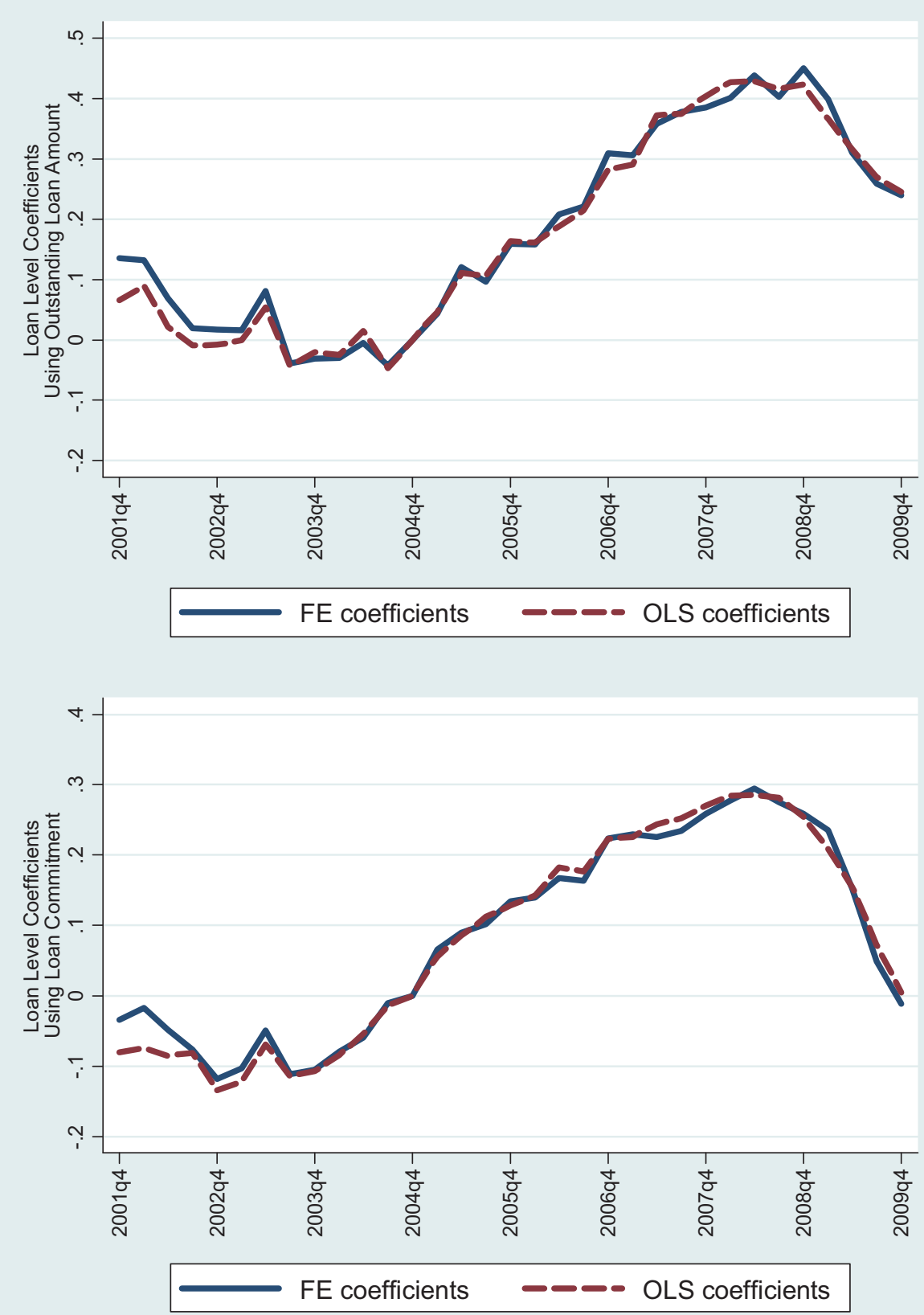

The top panel plots the coefficient estimates for $\boldsymbol{\beta}^{t}$ for the following specification for each quarter $t$ :

$\boldsymbol{y}_{i j t}-\boldsymbol{y}_{i j, 04 q 4}=\boldsymbol{\alpha}^{t}+\boldsymbol{\beta}^{t} * \boldsymbol{R}$ Eexposure $e_{i, 2000}+\boldsymbol{\eta}_{j t}+\varepsilon_{i j t}$

where $\boldsymbol{y}$ is the natural logarithm of loan amount outstanding for firm $j$ from bank i. REexposure ${ }_{i, 2000}$ is the share of loan portfolio exposed to real estate for bank $i$ in 2000. The OLS coefficient estimates do not include the firm fixed effects term, $\boldsymbol{\eta}_{j t}$. The bottom panel repeats the same exercise after replacing $\boldsymbol{y}$ with the natural logarithm of loan commitment for firm $j$ from bank $i$. 
Figure 5

Firm-Level Credit Channel Coefficients By Quarter

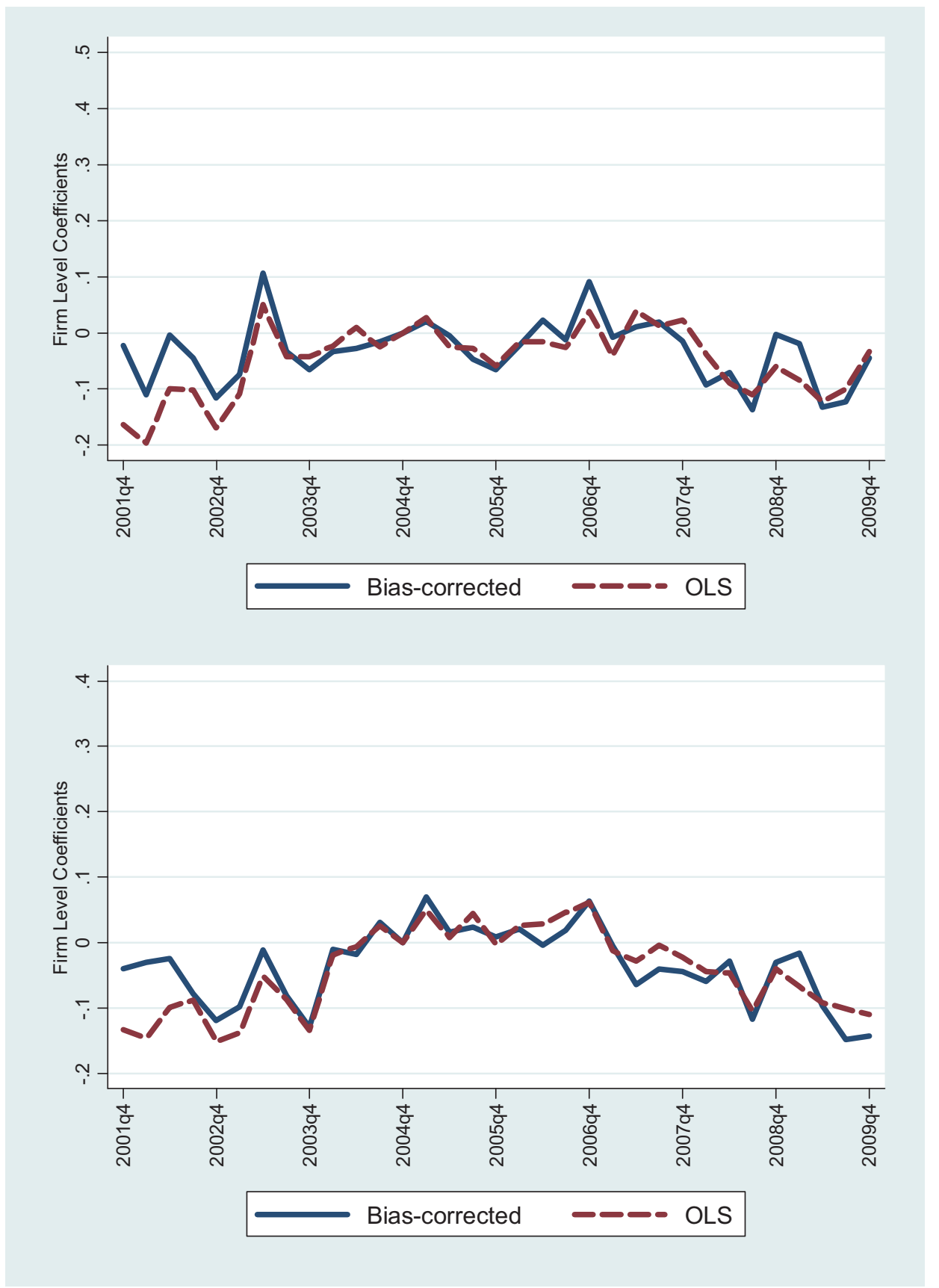

The top panel plots the coefficient estimates for $\overline{\boldsymbol{\beta}^{t}}$ for the following specification for each quarter $t$ :

$\overline{\boldsymbol{y}}_{j t}-\overline{\boldsymbol{y}}_{j, 04 q 4}=\overline{\boldsymbol{\alpha}}^{t}+\overline{\boldsymbol{\beta}}^{t} * \overline{\boldsymbol{R E e x p o s u r e}}_{j, 2000}+\overline{\boldsymbol{\varepsilon}}_{j t}$

where $\overline{\boldsymbol{y}}$ is the natural logarithm of total credit outstanding for firm $j$. $\overline{\boldsymbol{R E}} \boldsymbol{e x p o s u r e}_{j, 2000}$ is the average real estate exposure in 2000 of banks lending to firm $j$ at time $t$. The solid line in top panel "bias corrects" the coefficient estimate according to equation (3) in the paper. The bottom panel repeats the same exercise after replacing $\overline{\boldsymbol{y}}$ with the natural logarithm of total commitment for firm $j$. 
Figure 6

\section{Loan Terms Credit Channel Coefficients By Quarter}
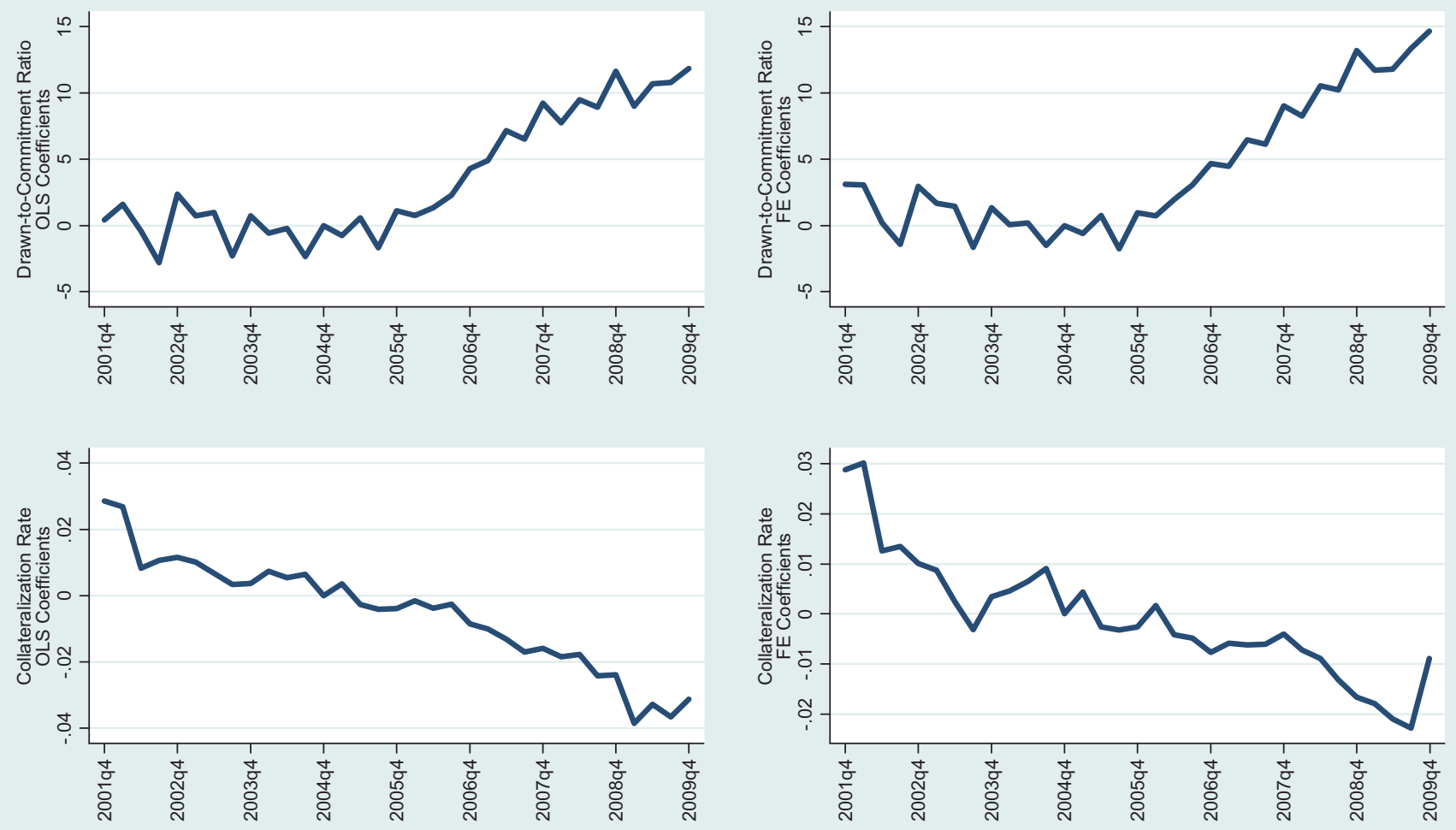

The top panel plots the coefficient estimates for $\boldsymbol{\beta}^{t}$ for the following specification for each quarter $t$ :

$\boldsymbol{y}_{i j t}-\boldsymbol{y}_{i j, 04 q 4}=\boldsymbol{\alpha}^{t}+\boldsymbol{\beta}^{t} * \boldsymbol{R E}$ exposure $\boldsymbol{e}_{i, 2000}+\boldsymbol{\eta}_{j t}+\boldsymbol{\varepsilon}_{i j t}$

where $\boldsymbol{y}$ is the drawn to commitment ratio for firm $j$ from bank $i$. REexposure $\boldsymbol{i}_{\boldsymbol{i}, 2000}$ is the share of loan portfolio exposed to real estate for bank $i$ in 2000. The OLS coefficient estimates do not include the firm fixed effects term, $\boldsymbol{\eta}_{j t}$. The bottom panel repeats the same exercise after replacing $\boldsymbol{y}$ with collateralization rate of loan for firm $j$ from bank $i$. 
Figure 7

Extensive Margin Bank Credit Channel Coefficients
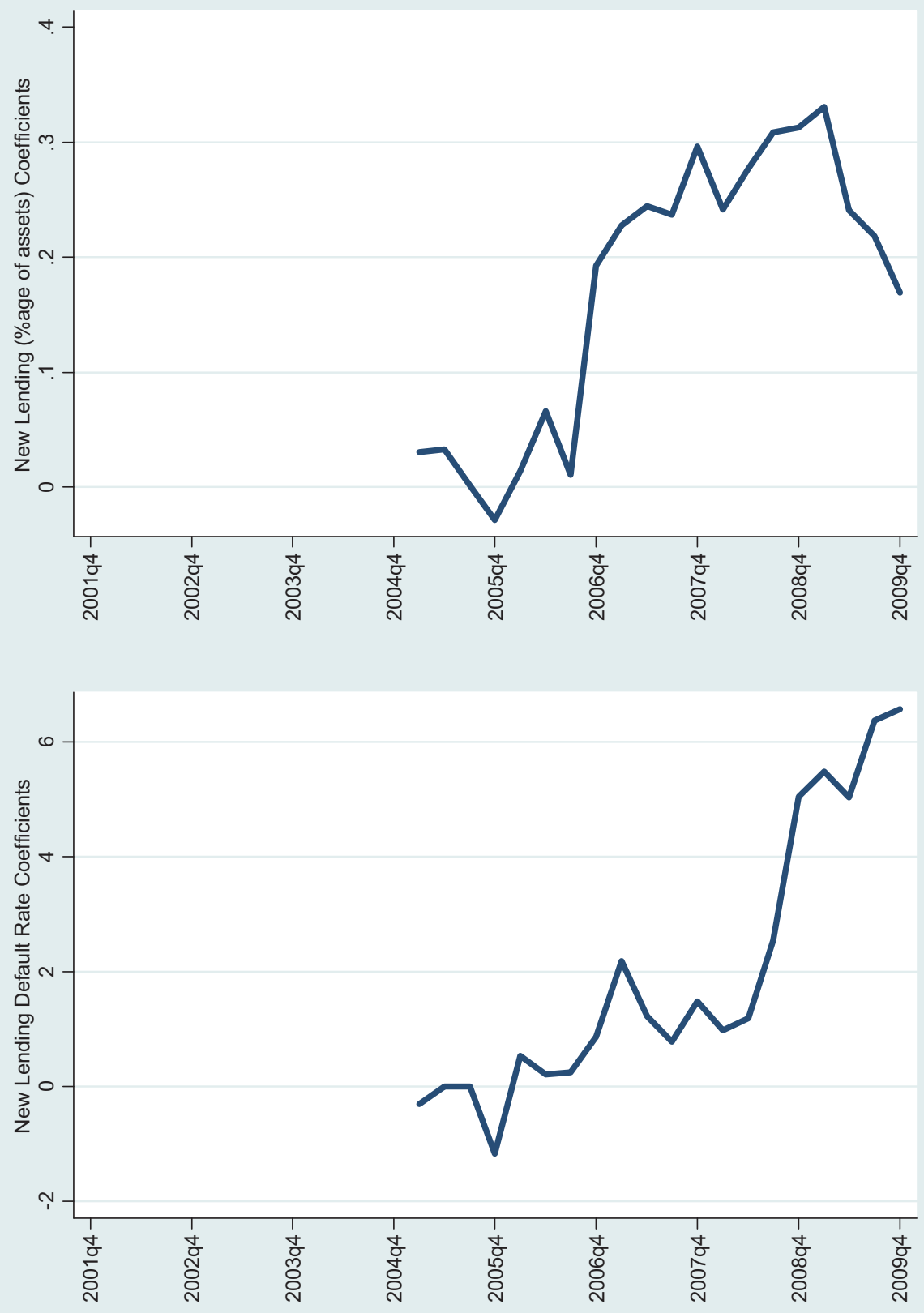

The top panel plots the coefficient estimates for $\boldsymbol{\beta}^{t}$ for the following specification for each quarter $t$ :

$\boldsymbol{y}_{i t}=\boldsymbol{\alpha}^{t}+\boldsymbol{\beta}^{t} * \boldsymbol{R E}$ exposure $\boldsymbol{e}_{i, 2000}+\boldsymbol{\varepsilon}_{i j t}$

where $\boldsymbol{y}$ is the ratio of credit given to new clients since 200494 and total outstanding loans of bank $i$. REexposure ${ }_{i, 2000}$ is the share of loan portfolio exposed to real estate for bank $i$ in 2000. The bottom panel repeats the same exercise after replacing $\boldsymbol{y}$ with the default rate for new credit. 
Table I

Simulation Of The Lending Channel $-\boldsymbol{\beta}=0.5$

\begin{tabular}{|c|c|c|c|c|c|c|c|c|c|}
\hline \multicolumn{10}{|c|}{ Panel A } \\
\hline \multirow[b]{2}{*}{$\rho$} & \multicolumn{3}{|c|}{$\Lambda=0 \%$} & \multicolumn{3}{|c|}{$\Lambda=50 \%$} & \multicolumn{3}{|c|}{$\Lambda=100 \%$} \\
\hline & -0.50 & 0.00 & 0.50 & -0.50 & 0.00 & 0.50 & -0.50 & 0.00 & 0.50 \\
\hline$\widehat{\beta}_{O L S}$ & 0.0619 & 0.5036 & 0.9514 & 0.0522 & 0.4966 & 0.9425 & 0.0627 & 0.5016 & 0.9395 \\
\hline$\widehat{\beta}_{F E}$ & 0.5000 & 0.4998 & 0.4999 & 0.4994 & 0.4997 & 0.4997 & 0.4995 & 0.5009 & 0.4999 \\
\hline$\widehat{\bar{\beta}}_{O L S}$ & -0.2497 & 0.5025 & 1.2709 & -0.5057 & 0.2432 & 1.0109 & -0.7446 & 0.0009 & 0.7536 \\
\hline $\bar{\beta}$ & 0.4941 & 0.4942 & 0.5008 & 0.2510 & 0.2496 & 0.2599 & -0.0058 & -0.0009 & 0.0098 \\
\hline \multicolumn{10}{|c|}{ Panel B } \\
\hline & \multicolumn{3}{|c|}{$\Lambda=0 \%$} & \multicolumn{3}{|c|}{$\Lambda=50 \%$} & \multicolumn{3}{|c|}{$\Lambda=100 \%$} \\
\hline$\rho$ & -0.50 & 0.00 & 0.50 & -0.50 & 0.00 & 0.50 & -0.50 & 0.00 & 0.50 \\
\hline$\widehat{\beta}_{O L S}$ & 0.0551 & 0.4904 & 0.9195 & 0.0567 & 0.4915 & 0.9130 & 0.0625 & 0.4951 & 0.9260 \\
\hline$\widehat{\beta}_{F E}$ & 0.4999 & 0.5003 & 0.4996 & 0.4988 & 0.5002 & 0.4991 & 0.5007 & 0.5006 & 0.4999 \\
\hline$\widehat{\bar{\beta}}_{O L S}$ & -0.1005 & 0.4921 & 1.0854 & -0.3265 & 0.2537 & 0.8365 & -0.5917 & -0.0050 & 0.5903 \\
\hline $\bar{\beta}$ & 0.4854 & 0.5066 & 0.5295 & 0.2555 & 0.2667 & 0.2894 & -0.0098 & 0.0030 & 0.0250 \\
\hline dropped & 0.3811 & 0.3725 & 0.3685 & 0.3790 & 0.3743 & 0.3671 & 0.3799 & 0.3743 & 0.3702 \\
\hline
\end{tabular}

This table reports the mean of 100 OLS and FE parameter estimates of the lending channel at the loan level

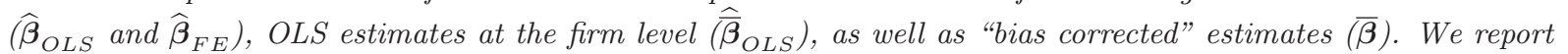
parameter estimates for different correlation values between the firm-and bank-speficic shocks at the loan level ranging from $\boldsymbol{\rho}=-0.50$ to $\boldsymbol{\rho}=0.50$ for different substitution levels $\boldsymbol{\Lambda}$ assuming normally distributed shocks with a mean 0 of and a standard deviation of 1 . In Panel $B$ we allow for the possibility that loans are dropped. 
Table II

Summary Statistics

\begin{tabular}{|c|c|c|c|c|c|c|}
\hline & \multicolumn{3}{|c|}{ All Firms } & \multicolumn{3}{|c|}{ Multiple Relationsship Firms } \\
\hline & $\mathrm{N}$ & Mean & Std Dev & $\mathrm{N}$ & Mean & Std Dev \\
\hline \multicolumn{7}{|l|}{ Loan Level Variables } \\
\hline Banks initial exposure to real estate assets & 67,838 & 0.466 & 0.156 & 51,397 & 0.460 & 0.158 \\
\hline Loan amount outstanding (2004Q4) & 67,838 & 288.1 & 3191.9 & 51,397 & 295.899 & 1637.3 \\
\hline Log loan amount within firm (2004Q4) & 63,941 & 0.000 & 0.852 & 49,787 & 0.000 & 0.966 \\
\hline Loan amount committed (2004Q4) & 67,838 & 367 & 3608.2 & 51,397 & 376.4 & 2169.2 \\
\hline Default Rate (2004Q4) & 63,941 & 0.019 & 0.134 & 49,787 & 0.017 & 0.129 \\
\hline Loan drawn to commitment ratio (2004Q4) & 67,838 & 81.066 & 30.752 & 51,397 & 83.2 & 27.9 \\
\hline Collateralization rate $(2004 \mathrm{Q} 4)$ & 67,838 & 0.195 & 0.371 & 51,397 & 0.148 & 0.330 \\
\hline Maturity greater than 5 years (2004Q4) & 67,838 & 0.230 & 0.390 & 51,397 & 0.185 & 0.356 \\
\hline$\Delta \log$ loan amount, $01 \mathrm{Q} 4$ to $04 \mathrm{Q} 4$ & 33,274 & -0.004 & 1.146 & 26,262 & 0.013 & 1.145 \\
\hline$\Delta$ default rate, $01 \mathrm{Q} 4$ to $04 \mathrm{Q} 4$ & 33,274 & 0.020 & 0.151 & 26,262 & 0.019 & 0.146 \\
\hline$\Delta \log$ loan amount, $04 \mathrm{Q} 4$ to $07 \mathrm{Q} 4$ & 42,609 & 0.057 & 1.223 & 32,647 & 0.059 & 1.217 \\
\hline$\Delta$ log loan amount, 04Q4 to 07Q4 (within firm) & 42,609 & 0.000 & 0.754 & 32,647 & 0.000 & 0.861 \\
\hline$\Delta$ default rate, $04 \mathrm{Q} 4$ to $07 \mathrm{Q} 4$ & 42,609 & 0.019 & 0.140 & 32,647 & 0.021 & 0.147 \\
\hline$\Delta \log$ loan amount, 07Q4 to 09Q4 & 31,298 & -0.250 & 1.016 & 23,322 & -0.252 & 1.034 \\
\hline$\Delta$ default rate, $07 \mathrm{Q} 4$ to $09 \mathrm{Q} 4$ & 31,298 & 0.061 & 0.241 & 23,322 & 0.074 & 0.263 \\
\hline \multicolumn{7}{|l|}{ Firm Level Variables } \\
\hline Banks initial exposure to real estate assets & 29,848 & 0.471 & 0.131 & 15,697 & 0.463 & 0.111 \\
\hline Number of banking relationships (2004Q4) & 29,848 & 2.250 & 1.848 & 15,697 & 3.302 & 2.017 \\
\hline Loan amount outstanding (2004Q4) & 29,848 & 662 & 6720.6 & 15,697 & 982.507 & 7101.2 \\
\hline Commitment amount (2004Q4) & 29,848 & 836.5 & 7833.6 & 15,697 & 1249.2 & 8681.9 \\
\hline Default Rate (2004Q4) & 29,848 & 0.021 & 0.135 & 15,697 & 0.017 & 0.119 \\
\hline Total Assets (2004Q4) & 14,984 & 4547.1 & 52221 & 9,093 & 6238.4 & 66362.5 \\
\hline Total Sales (2004Q4) & 14,984 & 5155.4 & 67860 & 9,093 & 7028 & 86285.2 \\
\hline Total Employees & 12,672 & 28.951 & 278.7 & 7,850 & 37.263 & 351.6 \\
\hline$\Delta \log$ loan amount, 01Q4 to 04Q4 & 20,998 & 0.146 & 1.193 & 12,627 & 0.384 & 1.019 \\
\hline$\Delta$ default rate, $01 \mathrm{Q} 4$ to $04 \mathrm{Q} 4$ & 20,998 & 0.017 & 0.142 & 12,627 & 0.015 & 0.125 \\
\hline$\Delta \log$ sales, $01 \mathrm{Q} 4$ to $04 \mathrm{Q} 4$ & 8,606 & 0.213 & 0.627 & 5,837 & 0.23 & 0.587 \\
\hline$\Delta \log$ loan amount, 04Q4 to 07Q4 & 25,154 & 0.214 & 1.263 & 14,074 & 0.048 & 1.098 \\
\hline$\Delta$ default rate, $04 \mathrm{Q} 4$ to $07 \mathrm{Q} 4$ & 25,154 & 0.018 & 0.137 & 14,074 & 0.023 & 0.154 \\
\hline$\Delta \log$ sales, $04 \mathrm{Q} 4$ to $07 \mathrm{Q} 4$ & 11,088 & 0.232 & 0.68 & 7,019 & 0.221 & 0.626 \\
\hline$\Delta \log$ loan amount, 07Q4 to 09Q4 & 22,120 & -0.204 & 0.942 & 12,681 & -0.232 & 0.923 \\
\hline$\Delta$ default rate, $07 \mathrm{Q} 4$ to $09 \mathrm{Q} 4$ & 22,120 & 0.050 & 0.209 & 12,681 & 0.063 & 0.230 \\
\hline$\Delta \log$ sales, $07 \mathrm{Q} 4$ to $09 \mathrm{Q} 4$ & 11,191 & 0.058 & 0.392 & 6,932 & 0.049 & 0.363 \\
\hline \multicolumn{7}{|l|}{ Bank Level Variables } \\
\hline Total Assets (2004Q4) & 192 & $7.8 \mathrm{E}+06$ & $2.5 \mathrm{E}+07$ & & & \\
\hline Initial exposure to real estate assets & 191 & 0.440 & 0.157 & & & \\
\hline Capital ratio (2004Q4) & 191 & 6.686 & 3.922 & & & \\
\hline Return on assets (2004Q4) & 191 & 0.945 & 0.483 & & & \\
\hline
\end{tabular}

This table presents summary statistics for loans outstanding as of 2004Q4. The underlying data represents a $10 \%$ random sample of all loans in Spain, with sampling done at firm level. A loan is defined as a firm-bank pair, i.e. separate loans from a bank to the same firm are aggregated at the firm level. Multiple Relationship firms have at least two banking relationships as of the fourth quarter of 2004. 
Table III

Securitization and Initial Real Estate Exposure

\begin{tabular}{|c|c|c|c|c|c|}
\hline & \multicolumn{2}{|c|}{$\begin{array}{c}\Delta \text { Securitized Assets Over } \\
\text { Total Assets ('04 to '07) }\end{array}$} & \multirow{2}{*}{$\begin{array}{c}\text { Securitized } \\
\text { Assets Over } \\
\text { Total Assets } \\
(2007) \\
(3)\end{array}$} & \multicolumn{2}{|c|}{$\Delta \log$ Bank Credit ('04 to '07) } \\
\hline & $(1)$ & $(2)$ & & $(4)$ & $(5)$ \\
\hline Bank RE Exposure & $\begin{array}{l}0.197 * * * \\
(0.064)\end{array}$ & $\begin{array}{l}0.274 * * * \\
(0.075)\end{array}$ & $\begin{array}{l}0.349 * * * \\
(0.084)\end{array}$ & $\begin{array}{l}1.01 * * * \\
(0.32)\end{array}$ & \\
\hline $\begin{array}{l}\text { Securitized Assets Over } \\
\text { Total Assets (2004 to 2007) }\end{array}$ & & & & & $\begin{array}{l}1.12 * * * \\
(0.415)\end{array}$ \\
\hline Constant & $\begin{array}{c}0.036 \\
(0.029)\end{array}$ & $\begin{array}{r}0.073 * \\
(0.039)\end{array}$ & $\begin{array}{l}0.15 * * * \\
(0.041)\end{array}$ & $\begin{array}{c}-0.014 \\
(0.18)\end{array}$ & $\begin{array}{l}0.24 * * \\
(0.12)\end{array}$ \\
\hline & OLS & WLS & WLS & WLS & WLS \\
\hline $\mathrm{N}$ & 179 & 179 & 179 & 178 & 178 \\
\hline$R^{2}$ & 0.063 & 0.14 & 0.14 & 0.18 & 0.12 \\
\hline
\end{tabular}

This table presents bank-level regressions relating the change in securitized assets and change in bank credit between $2004 Q 4$ and 2007Q4 to a banks initial exposure to real estate assets. Banks initial exposure to real estate is defined as the fraction of total loans that is given out to the real estate sector (residential, commercial, and construction) as of 2000Q1. All specifications report robust standard errors. ***,**, ${ }^{*}$ imply that coefficient estimates are significant at 1\%, 5\% and 10\% level, respectively. 
Table IV

Correlation Between Banks Exposure To Real Estate And Initial Characteristics

\begin{tabular}{|c|c|c|c|c|}
\hline & Coeff & s.e. & Coeff & s.e. \\
\hline \multicolumn{5}{|l|}{ Bank Level Variables (2000Q1) } \\
\hline Return on assets & 1.896 & $(1.569)$ & & \\
\hline Total Default Rate & 0.0009 & $(0.0046)$ & & \\
\hline Capital Ratio & -0.705 & $(2.642)$ & & \\
\hline Cajas? & $0.935 * * *$ & $(0.120)$ & & \\
\hline \multicolumn{5}{|l|}{ Firm Level Variables (2005Q4) } \\
\hline Default rate & 0.0104 & $(0.0114)$ & & \\
\hline Total assets & $-7549.001 * * *$ & $(1739.05)$ & & \\
\hline Log total assets & $-0.846 * * *$ & $(0.147)$ & & \\
\hline Total credit & $-469.860 * *$ & $(253.369)$ & & \\
\hline Log total credit & $-0.802 * *$ & $(0.379)$ & & \\
\hline Total sales & $-8349.19 * * *$ & $(1836.714)$ & & \\
\hline Log total sales & $-1.225 * * *$ & $(0.173)$ & & \\
\hline Number of banking relationships & -0.004 & $(0.343)$ & & \\
\hline Tangible assets ratio & $19.109 * * *$ & $(2.912)$ & & \\
\hline Short term debt ratio & $-27.557 * * *$ & $(3.213)$ & & \\
\hline \multicolumn{3}{|l|}{ Loan Level Variables (2005Q4) } & \multicolumn{2}{|c|}{ With firm fixed effects } \\
\hline Default Rate & 0.013 & $(0.008)$ & 0.007 & $(0.004)$ \\
\hline Loan amount & $-300.276 * * *$ & $(126.888)$ & -68.16 & $(83.267)$ \\
\hline Log loan amount & -0.123 & $(0.312)$ & 0.147 & $(0.285)$ \\
\hline Collateralization rate & $0.266 * * *$ & $(0.048)$ & $0.150 * * *$ & $(0.034)$ \\
\hline Maturity greater than 5 years & $0.204 * * *$ & $(0.092)$ & 0.106 & $(0.069)$ \\
\hline
\end{tabular}

This table regresses various bank, firm and loan characteristics on banks exposure to real estate assets in 2000, and reports the coefficient and standard error on bank exposure variable. Banks initial exposure to real estate is defined as the fraction of total loans that is given out to the real estate sector (residential, commercial, and construction) as of 2000Q1. ***,**, ${ }^{*}$ imply that coefficient estimates are significant at $1 \%, 5 \%$ and $10 \%$ level, respectively. 
Table V

Securitization And The Credit Channel

\begin{tabular}{|c|c|c|c|c|c|c|c|c|c|}
\hline & \multicolumn{5}{|c|}{$\Delta$ Log Drawn (04Q4 to 07Q4) } & \multirow{2}{*}{$\begin{array}{c}\Delta \text { Log } \\
\text { Drawn } \\
(01 \mathrm{Q} 4 \text { to } \\
\text { 04Q4) } \\
(6)\end{array}$} & \multirow{2}{*}{$\begin{array}{c}\text { Loan } \\
\text { Dropped? } \\
(7)\end{array}$} & \multirow{2}{*}{$\begin{array}{c}\text { Tobit } \\
(8)\end{array}$} & \multirow[t]{2}{*}{$\begin{array}{c}\Delta \text { Firm- } \\
\text { Level Log } \\
\text { Drawn } \\
\text { (04Q4 to } \\
\text { 07Q4) } \\
(9)\end{array}$} \\
\hline & $(1)$ & $(2)$ & $(3)$ & $(4)$ & $(5)$ & & & & \\
\hline Bank RE Exposure & $\begin{array}{l}0.366 * * * \\
(0.099)\end{array}$ & $\begin{array}{l}0.404 * * * \\
(0.104)\end{array}$ & $\begin{array}{l}0.386 * * * \\
(0.113)\end{array}$ & $\begin{array}{l}0.382 * * * \\
(0.111)\end{array}$ & $\begin{array}{r}0.419 * \\
(0.225)\end{array}$ & $\begin{array}{r}-0.135 \\
(0.145)\end{array}$ & $\begin{array}{l}-0.245 * * * \\
(0.070)\end{array}$ & $\begin{array}{l}0.882 * * * \\
(0.285)\end{array}$ & $\begin{array}{c}0.023 \\
(0.100)\end{array}$ \\
\hline Firm-Bank Type fixed effects & No & No & No & No & Yes & No & No & No & - \\
\hline Loan controls & No & No & No & Yes & No & No & No & No & - \\
\hline Firm fixed effects & No & No & Yes & Yes & - & Yes & Yes & No & No \\
\hline $\begin{array}{l}\text { Data restricted to firms with } \\
\text { multiple relationships }\end{array}$ & No & Yes & Yes & Yes & Yes & Yes & Yes & Yes & Yes \\
\hline $\mathrm{N}$ & 42,609 & 32,647 & 32,647 & 32,647 & 32,647 & 26,262 & 51,397 & 51,397 & 14,074 \\
\hline$R^{2}$ & 0.002 & 0.003 & 0.50 & 0.51 & 0.70 & 0.53 & 0.46 & & 0.00 \\
\hline
\end{tabular}

This table presents coefficient estimates from specifications at the loan (firm-bank) level relating the growth in bank credit from $2004 Q 4$ to $2007 Q 4$ to lending banks initial exposure to real estate. Column (8) runs a tobit specification, taking into account that change in lending is censored for firms dropped by banks (or log loan amount dropping by more than -1.82 , i.e. the bottom 5 th percentile). Banks initial exposure to real estate is the fraction of total loans that is given to mortgages and construction/ real estate as of 2000:Q1. Loan controls include collateral and maturity. A firm is defined to have multiple relationships if it borrows from at least two banks of 2004:Q4. All specifications include a constant (not reported) and errors are cluster at the bank level. ***,**,* Coefficient estimate statistically distinct from 0 at the $1 \%, 5 \%$ and $10 \%$ levels, respectively. 
Table VI

Securitization And Loan Terms

\begin{tabular}{|c|c|c|c|c|c|c|c|c|c|}
\hline & \multicolumn{9}{|c|}{ Change in Loan conditions from 2004Q4 to 2007Q4 } \\
\hline & \multicolumn{3}{|c|}{ Drawn to Committed Ratio } & \multicolumn{3}{|c|}{ Collateralization Rate } & \multicolumn{3}{|c|}{ Long-term maturity } \\
\hline & $(1)$ & $(2)$ & $(3)$ & $(4)$ & $(5)$ & $(6)$ & $(7)$ & $(8)$ & $(9)$ \\
\hline Bank RE Exposure & $\begin{array}{l}8.28 * * * \\
(2.69)\end{array}$ & $\begin{array}{l}8.33 * * * \\
(2.65)\end{array}$ & $\begin{array}{l}8.51 * * * \\
(3.34)\end{array}$ & $\begin{array}{l}-0.016 \\
(0.0114)\end{array}$ & $\begin{array}{l}-0.065 * * \\
(0.033)\end{array}$ & $\begin{array}{c}-0.048 \\
(0.03)\end{array}$ & $\begin{array}{c}0.134 \\
(0.084)\end{array}$ & $\begin{array}{l}0.16 * * \\
(0.067)\end{array}$ & $\begin{array}{l}0.13 * * \\
(0.062)\end{array}$ \\
\hline Loan Controls & & Yes & Yes & & Yes & Yes & & Yes & Yes \\
\hline Firm fixed effects & & & Yes & & & Yes & & & Yes \\
\hline $\begin{array}{l}\text { Data restricted to firms } \\
\text { with multiple relationships }\end{array}$ & Yes & Yes & Yes & Yes & Yes & Yes & Yes & Yes & Yes \\
\hline $\mathrm{N}$ & 32,647 & 32,647 & 32,647 & 32,647 & 32,647 & 32,647 & 32,647 & 32,647 & 32,647 \\
\hline$R^{2}$ & 0.0027 & 0.0410 & 0.50 & 0.0001 & 0.25 & 0.62 & 0.0052 & 0.15 & 0.46 \\
\hline
\end{tabular}

This table presents coefficient estimates from specifications at the loan (firm-bank) level relating the change in loan conditions from $2004 Q 4$ to $2007 Q 4$ to lending banks exposure to real estate. We use three different loan conditions: change in drawn to committed credit in column 1 to 3 , change in collateralization rate in column 4 to 6 and change in long term maturity (over 5 years) in column 7 to 9. Loan controls in (2) and (3) include maturity and collateralization rate as of 2004Q4 as well as changes in these two variables during 2004-0\%. Loan controls in (5) and (6) have maturity as of 2004Q4 as well as change in this variable during 2004-07. Loan controls in (8) and (9) have collateralization rate as of 200404 as well as change in this variable during 2004-07. All specifications include a constant (not reported) and errors are cluster at the bank level. Banks initial exposure to real estate is defined as the fraction of total loans that is given out to the real estate sector (residential, commercial, and construction) as of $2000 Q 1 .{ }^{* * *},{ }^{* *},{ }^{*}$ imply that coefficient estimates are significant at 1\%, 5\% and 10\% level, respectively. 
Table VII

Firm Outcomes

\begin{tabular}{|c|c|c|c|c|c|c|}
\hline & $\Delta($ drawn to commit $)$ & $\Delta(\%$ long-term $)$ & $\Delta($ collateral rate $)$ & $\Delta($ default rate $)$ & $\Delta(\log$ sales $)$ & $\Delta($ employees $)$ \\
\hline & $(1)$ & $(2)$ & $(3)$ & $(4)$ & $(5)$ & $(6)$ \\
\hline Firm Banks' RE Exposure & $\begin{array}{l}6.86 * * * \\
(1.26)\end{array}$ & $\begin{array}{l}0.054 * * \\
(0.026)\end{array}$ & $\begin{array}{l}-0.10 * * * \\
(0.019)\end{array}$ & $\begin{array}{c}0.0008 \\
(0.022)\end{array}$ & $\begin{array}{c}-0.0025 \\
(0.059)\end{array}$ & $\begin{array}{c}0.045 \\
(0.081)\end{array}$ \\
\hline Bias-Corrected Coefficient & 7.38 & 0.066 & -0.074 & & & \\
\hline $\begin{array}{l}\text { Data restricted to firms with } \\
\text { multiple relationships }\end{array}$ & Yes & Yes & Yes & Yes & Yes & Yes \\
\hline $\mathrm{N}$ & 14,277 & 14,277 & 14,277 & 14,277 & 7,019 & 5,964 \\
\hline$R^{2}$ & 0.0012 & 0.0005 & 0.0019 & 0 & 0 & 0.0001 \\
\hline
\end{tabular}

This table presents coefficient estimates from specifications at the firm level relating the growth in firm level outcomes to a firms banks initial exposure to real estate assets. Banks initial exposure to real estate is defined as the fraction of total loans that is given out to the real estate sector (residential, commercial, and construction) as of 2000Q1. Firm banks real estate exposure is the weighted average of a firms lending banks exposure to real estate as of 2000Q1. Bias-corrected coefficients are calculated using the methodology outline in equation (3) of the paper. The calculations are as follows: Column $(1), 7.38=6.86+(8.54-8.28) *\left(0.157^{2} / 0.111^{2}\right)$. Column (2), $0.066=0.054+(0.14-0.134)) *\left(0.157^{2} / 0.111^{2}\right)$. Column (3), $-0.074=-0.10+(-0.0030+0.016) *\left(0.157^{2} / 0.111^{2}\right)$. All specifications include a constant (not reported) and errors are cluster at the lead-bank level. ***,**,* imply that coefficient estimates are significant at $1 \%, 5 \%$ and $10 \%$ level, respectively. 
Table VIII

Extensive Margin - Extension of Credit to New Clients

\begin{tabular}{|c|c|c|c|c|c|}
\hline & $\begin{array}{c}\text { Log } \\
\text { Drawn }\end{array}$ & $\begin{array}{c}\text { Log } \\
\text { Commitment }\end{array}$ & $\begin{array}{c}\text { Drawn } \\
\text { Normalized }\end{array}$ & $\begin{array}{l}\text { New Firms } \\
\text { Drawn } \\
\text { Normalized }\end{array}$ & Defaults \\
\hline & (1) & $(2)$ & $(3)$ & (4) & $(5)$ \\
\hline Bank RE Exposure & $\begin{array}{l}1.97 * * \\
(0.79)\end{array}$ & $\begin{array}{l}1.69 * * \\
(0.73)\end{array}$ & $\begin{array}{l}0.665 * * * \\
(0.22)\end{array}$ & $\begin{array}{l}0.382 * * * \\
(0.153)\end{array}$ & $\begin{array}{l}0.0657 * * \\
(0.0287)\end{array}$ \\
\hline Constant & $\begin{array}{l}7.99 * * * \\
(0.39)\end{array}$ & $\begin{array}{l}8.37 * * * \\
(0.37)\end{array}$ & $\begin{array}{l}0.193 * \\
(0.11)\end{array}$ & $\begin{array}{r}0.115 * \\
(0.060)\end{array}$ & $\begin{array}{c}0.0061 \\
(0.012)\end{array}$ \\
\hline $\mathrm{N}$ & 175 & 177 & 179 & 179 & 163 \\
\hline$R^{2}$ & 0.025 & 0.019 & 0.064 & 0.08 & 0.068 \\
\hline
\end{tabular}

This table presents coefficient estimates from specifications at the bank level relating lending given out to new clients by banks between 2004Q4 and 2007Q4 to a banks initial real estate exposure. Banks initial exposure to real estate is defined as the fraction of total loans that is given out to the real estate sector (residential, commercial, and construction) as of 2000Q1. ***,**, * imply that coefficient estimates are significant at 1\%, 5\% and 10\% level, respectively. All specifications report robust standard errors. 


\section{BANCO DE ESPAÑA PUBLICATIONS}

\section{WORKING PAPERS ${ }^{1}$}

1032 GABE J. DE BONDT, TUOMAS A. PELTONEN AND DANIEL SANTABÁRBARA: Booms and busts in China's stock market: Estimates based on fundamentals.

1033 CARMEN MARTÍNEZ-CARRASCAL AND JULIAN VON LANDESBERGER: Explaining the demand for money by nonfinancial corporations in the euro area: A macro and a micro view.

1034 CARMEN MARTÍNEZ-CARRASCAL: Cash holdings, firm size and access to external finance. Evidence for the euro area.

1035 CÉSAR ALONSO-BORREGO: Firm behavior, market deregulation and productivity in Spain.

1036 OLYMPIA BOVER: Housing purchases and the dynamics of housing wealth.

1037 DAVID DE ANTONIO LIEDO AND ELENA FERNÁNDEZ MUÑOZ: Nowcasting Spanish GDP growth in real time: "One and a half months earlier".

1038 FRANCESCA VIANI: International financial flows, real exchange rates and cross-border insurance.

1039 FERNANDO BRONER, TATIANA DIDIER, AITOR ERCE AND SERGIO L. SCHMUKLER: Gross capital flows: dynamics and crises.

1101 GIACOMO MASIER AND ERNESTO VILLANUEVA: Consumption and initial mortgage conditions: evidence from survey data.

1102 PABLO HERNÁNDEZ DE COS AND ENRIQUE MORAL-BENITO: Endogenous fiscal consolidations.

1103 CÉSAR CALDERÓN, ENRIQUE MORAL-BENITO AND LUIS SERVÉN: Is infrastructure capital productive? A dynamic heterogeneous approach.

1104 MICHAEL DANQUAH, ENRIQUE MORAL-BENITO AND BAZOUMANA OUATTARA: TFP growth and its determinants: nonparametrics and model averaging.

1105 JUAN CARLOS BERGANZA AND CARMEN BROTO: Flexible inflation targets, forex interventions and exchange rate volatility in emerging countries.

1106 FRANCISCO DE CASTRO, JAVIER J. PÉREZ AND MARTA RODRÍGUEZ VIVES: Fiscal data revisions in Europe.

1107 ANGEL GAVILÁN, PABLO HERNÁNDEZ DE COS, JUAN F. JIMENO AND JUAN A. ROJAS: Fiscal policy, structural reforms and external imbalances: a quantitative evaluation for Spain.

1108 EVA ORTEGA, MARGARITA RUBIO AND CARLOS THOMAS: House purchase versus rental in Spain.

1109 ENRIQUE MORAL-BENITO: Dynamic panels with predetermined regressors: likelihood-based estimation and Bayesian averaging with an application to cross-country growth.

1110 NIKOLAI STÄHLER AND CARLOS THOMAS: FiMod - a DSGE model for fiscal policy simulations.

1111 ÁLVARO CARTEA AND JOSÉ PENALVA: Where is the value in high frequency trading?

1112 FILIPA SÁ AND FRANCESCA VIANI: Shifts in portfolio preferences of international investors: an application to sovereign wealth funds.

1113 REBECA ANGUREN MARTÍN: Credit cycles: Evidence based on a non-linear model for developed countries.

1114 LAURA HOSPIDO: Estimating non-linear models with multiple fixed effects: A computational note.

1115 ENRIQUE MORAL-BENITO AND CRISTIAN BARTOLUCCI: Income and democracy: Revisiting the evidence.

1116 AGUSTÍN MARAVALL HERRERO AND DOMINGO PÉREZ CAÑETE: Applying and interpreting model-based seasonal adjustment. The euro-area industrial production series.

1117 JULIO CÁCERES-DELPIANO: Is there a cost associated with an increase in family size beyond child investment? Evidence from developing countries.

1118 DANIEL PÉREZ, VICENTE SALAS-FUMÁS AND JESÚS SAURINA: Do dynamic provisions reduce income smoothing using loan loss provisions?

1119 GALO NUÑO, PEDRO TEDDE AND ALESSIO MORO: Money dynamics with multiple banks of issue: evidence from Spain 1856-1874.

1120 RAQUEL CARRASCO, JUAN F. JIMENO AND A. CAROLINA ORTEGA: Accounting for changes in the Spanish wage distribution: the role of employment composition effects.

1. Previously published Working Papers are listed in the Banco de España publications catalogue. 
1121 FRANCISCO DE CASTRO AND LAURA FERNÁNDEZ-CABALLERO: The effects of fiscal shocks on the exchange rate in Spain

1122 JAMES COSTAIN AND ANTON NAKOV: Precautionary price stickiness.

1123 ENRIQUE MORAL-BENITO: Model averaging in economics.

1124 GABRIEL JIMÉNEZ, ATIF MIAN, JOSÉ-LUIS PEYDRÓ AND JESÚS SAURINA: Local versus aggregate lending channels: the effects of securitization on corporate credit supply.

\begin{tabular}{|r|c|}
\hline & Unidad de Publicaciones \\
BANCODEESPANA & Alcalá 522, 28027 Madrid \\
Eurosistema & Telephone +34 91 338 6363. Fax +34913386488 \\
& E-mail: publicaciones@bde.es \\
www.bde.es
\end{tabular}

